\title{
„ATELIERUL” DE PROCESARE A MINEREULUI AURIFER ŞI NECROPOLA ROMANĂ DE INCINERAȚIE DE LA JIG-PICIORAG, ROŞIA MONTANĂ
}

\author{
Mihaela Simion, Ionuț Bocan, Decebal Vleja, Emil Dumitraşcu
}

\section{THE “WORKSHOP” FOR PROCESSING AURIFEROUS ORE AND THE CREMATION NECROPOLIS FROM JIG-PICIORAG, ROŞIA MONTANĂ}

The five necropolises and two funerary areas investigated up to now at Roşia Montană have a particular feature due to the economic context in which are involved the ancient communities attested from an archaeological perspective - in here during the Roman period, namely an environment linked to the exploitation of the gold and silver deposits existing in the region. It is obvious that certain aspects regarding the funerary rite and ritual of these communities are influenced both by an ethnical and cultural conditioning, as well as by the economic one, induced by the special character of the site.

An elementary mapping of all these funerary esembles indicated very clearly the fact that all the investigated necropolises are located in close proximity of the exploitation areas of the auriferous deposit.

From this point of view, a special attention is drawn by the archaeological context documented on the Jig-Piciorag site, where was visible a succesion of usage phases, namely exploitation of mineral resources ? - primary processing - arrangement and use as a funerary space.

The article presents the results of the researches from the 2003 campaign, when a team from the National History Museum of Romania investigated a structure having a functionality linked to the exploitation and primary processing of the auriferous ore durig the Roman period. The structure consists of a constructive arrangement, a system of channels, a centraly located hearth and a basin. After the abandonment of these phase, the perimeter was used as a burial site, being in close relation with the Roman cremation necropolis located nearby.

Keywords: Roşia Montană [Alburnus Maior], ancient mining site (Roman period), exploitation of mineral resources, primary processing, funerary space.

Cuvinte cheie: Roşia Montană [Alburnus Maior], sit antic minier (epoca romană), exploatarea resurselor minerale, prelucrare primară, spațiu funerar.

Războaiele dintre daci şi romani din anii 101-102 şi 105-106 au avut ca rezultat transformarea unei părți a fostului regat dac în provincie romană ${ }^{1}$. Cucerirea acestui nou teritoriu a fost determinată nu numai de rațiuni strategice, ci şi, fără îndoială, economice. Majoritatea cercetătorilor epocii romane sunt de acord în a accepta faptul că una dintre motivațiile cuceririi Daciei a fost

\footnotetext{
1 RE, IV, 1901, col. 2247-2252 s.v. Decebalus (G. Brandis); Patsch 1937; Daicoviciu 1972; Cizek 1980; Strobel 1984; Strobel 1998, 61-95.
} 
cea legată de bogăția în metale prețioase a regatului dac ${ }^{2}$.

Este astăzi clar, în urma cercetărilor din ultimii ani, că organizarea exploatărilor metalifere din noul teritoriu al Imperiului s-a făcut în perioada imediat următoare cuceririi propriu-zise, în paralel cu organizarea administrativă a noii provincii ${ }^{3}$. Specificul activităţii de extragere şi prelucrare a minereurilor neferoase a impus prezența unei forțe de muncă specializate. Astfel, în contextul organizării, pe scară largă, a colonizării provinciei Dacia, alături de elemente ex toto orbe romana, regiunea auriferă a beneficiat de un puternic aport de coloniști din aria traco-dalmato-iliră, cu vechi tradiții într-o astfel de activitate economică ${ }^{4}$.

Celebritatea anticului Alburnus Maior este conferită de faptul că localitatea este locul de descoperire a unor materiale epigrafice $\mathrm{cu}$ un caracter particular. Documente epigrafice deosebite prin unicitatea şi prin abundența informațiilor conținute, cele 25 de tăblițe cerate ${ }^{5}$ păstrate oferă informații precise asupra realităților economice, sistemului de habitat, vieții religioase şi a raporturilor juridice care guvernau comunitatea minieră de aici. Potrivit unei părți din literatura arheologică de specialitate, ele au fost puse la adăpost, în interiorul unor galerii miniere greu accesibile, într-un moment de criză, probabil legat de

\footnotetext{
2 Ioannes Lydus, De magistratibus, II, 28; Carcopino 1924, 28-34; Carcopino 1934, 73-86; Christescu 1926, 15-34; Macrea 1969, 298-306.

3 Situaţie similară cu cea constatată în organizarea districtelor miniere din Hispania (vezi: Pigagnol 1967; Davies 1935, 15-86; Tovar, Blázquez 1975; Domergue 1990, 179-214.

${ }^{4}$ Noeske 1977, 370-371; Wilkes 1969, 153-158; Popescu 1967, 182-190; Dušanic 1977, 52-94. Dušanic 1971, 241261; Rostovtzeff 1926, 221-225.

${ }^{5}$ Numărul descoperirilor este de probabil peste 30 , ele găsindu-se în colecțiile muzeelor din Berlin (TabCerD XIV), Blaj (TabCerD III, VII, VIII, XXI, XXII, XXV), Budapesta (TabCerD I, II, V, VI, IX, X, XII, XIII, XV, XVII, XIX, XX, XXIV), Cluj (TabCerD III, XI, XVIII) şi în colecția Bibliotecii Battyaneum din Alba Iulia (TabCerD IV).
}

atacurile marcomanice asupra Daciei din intervalul 167-170 p.Chr ${ }^{6}$.

Informațiile despre centrul antic de exploatare a aurului au fost completate, de-a lungul timpului, mai ales după conjunctura favorabilă reprezentată de momentul descoperirii tăbliţelor cerate, de aproximativ 75 de monumente epigrafice ${ }^{7}$. De cele mai multe ori acestea au locul de proveniență relativ sau redus doar la o succintă relatare. Practic, cu excepția unei săpături de salvare realizată în anii $80^{8}$, cercetarea arheologică în zonă a fost inexistentă.

Cercetările arheologice din perioada 2001-2007, desfăşurate în cadrul Programului Naţional de Cercetare Alburnus Maior, în perimetrul actualei localități Roşia Montană, au avut ca principală consecință, conturarea unei imagini, fundamentate pe argumente de ordin arheologic, a unei zone, legate, din punct de vedere socio-economic, în epoca romană, de activitatea de extragere şi prelucrare a zăcământului auro-argentifer. Principalele repere ale sistemului de organizare a zonei Roşia Montană în perioada romană sunt constituite, în stadiul actual al cercetării, de către următoarele elemente definitorii: a) zonele de exploatare a zăcământului auro-argentifer (Masivele Cetate, Cârnic, Jig, Orlea); b) anumite structuri de organizare ale habitatului (inclusiv zone sacre) şi a rețelei de drumuri aferente; c) cinci necropole şi două zone funerare romane de incineraţie (din care au fost cercetate integral peste 1450 de morminte).

Cele cinci necropole şi două zone funerare cercetate până în prezent la Roşia Montană au un caracter particular, datorită contextului economic în care sunt implicate comunităţile atestate arheologic aici, în epoca romană, context legat de exploatarea zăcământului auro-argentifer din această

\footnotetext{
6 Tudor 1957, 31-40; Daicoviciu, Piso 1975, 159-160; Macrea 1969, 69.

${ }^{7}$ IDR III/3, Wollmann 1986, 253-295.

${ }^{8}$ Wollmann 1986, 253-295.
} 
regiune. Este de la sine înțeles că anumite aspecte referitoare la ritul şi ritualul funerar ale acestor comunități sunt influențate atât de condiționarea etnico-culturală, cât şi de cea economică, indusă de caracterul specific al sitului.

La o cartare elementară a acestor ansambluri funerare devine evident faptul că toate necropolele investigate sunt în imediata apropiere a zonelor de exploatare a zăcământului aurifer (pl. 1).

O atenție particulară o suscită, din acest punct de vedere, situația arheologică constatată în cazul punctului Jig-Piciorag, unde este vizibilă succesiunea Exploatare Resurse Minerale? - Prelucrare primară Amenajare ca spațiu funerar.

Obiectivul arheologic care face obiectul analizei noastre a fost descoperit în campania de cercetări arheologice din anul 2003, fiind amplasat în imediata vecinătate a masivului Jig (punctul Piciorag) pe proprietăţile Gomboş Artemiza, Bara Lucreția şi Câmpean Elena. Au fost deschise un număr de 60 de unități de săpătură ${ }^{9}$, ceea ce a permis decopertarea integrală a unei suprafețe de cca. $1300 \mathrm{~m}^{2}$ (pl. 2, pl. 6/foto 1).

Proprietatea Gomboş Artemiza, pe care se concentrează majoritatea complexelor arheologice analizate, este situată la aproximativ 200 m sud față de masivul Jig, învecinându-se la est cu proprietatea Bara Lucreția, la nord-est cu proprietatea Jurca, la vest şi la sud cu drumul vicinal care străbate zona Țarina. Configurația terenului iese în evidență prin anomaliile de relief şi prin diferența mare de nivel atât pe axa nord-sud cât mai ales pe axa est-vest, precum şi prin prezența a trei platouri, dintre care două situate lângă drumul menționat. Principalele

943 unități de săpătura pe proprietatea Gomboș Artemiza şi 17 unități de săpătură pe proprietatea Câmpean Elena. Colectivul de cercetare al MNIR a fost format din Paul Damian, Mihaela Simion, Cătălina Neagu, Gabriel Bălan, Emil Dumitraşcu, Ionuț Bocan, Decebal Vleja şi Sorin Cleşiu. De asemenea o parte a perimetrului a fost investigat de către un colectiv de la Institutul Național de Arheologie „Vasile Pârvan”. rezultate ale cercetării arheologice în această zonă au constat în descoperirea unei noi zone funerare cu 34 morminte de incinerație şi a unei structuri constructive, precar conservate, care datorită situației arheologice constatate şi a inventarului arheologic mobil provenit din acest punct pare să aibă o funcționalitate legată de exploatarea şi prelucrarea primară a minereului metalifer ${ }^{10}$ (pl. 3).

\section{Stratigrafia generală a perimetrului investigat:}

Stratul vegetal, are o grosime variabilă de cca. 0,10-0,25 m. El constă într-un sediment preponderent argilos, de culoare maroniu închisă. Urmează un strat care se caracterizează prin prezența unui sediment de aceeaşi textură, de culoare brună, foarte afânat şi granulat, cu o grosime variabilă între $0,10-0,40 \mathrm{~m}$. Grosimea stratului nu este uniformă pe întregul platou de pe proprietatea Gomboş. În jumătatea de est a proprietății stratul este mult mai gros (cca. 0,70/-0,75 m). Sub acest strat, la adâncimea de 0,20/-0,65 $\mathrm{m}$, se înregistrează prezența lutului galben, extrem de compact. Acest sediment corespunde nivelului de amenajare a gropilor sepulcrale şi a nivelului pe care au fost surprinse urmele prezervate din structura constructivă investigată în acest punct. În jumătatea de est a zonei, stratul de lut galben este aproape inexistent fiind înlocuit de un sediment de rocă demineralizată, foarte alterată, sporadic cu urme de tratament termic, în care a fost practicată o rețea de canale de diverse dimensiuni şi adâncimi.

Necropola de incinerație este localizată, în stadiul actual al cercetării, pe proprietățile Gomboş Artemisa ${ }^{11}$, Bara Lucreția ${ }^{12}$ şi Câmpean Elena ${ }^{13}$. Gropile sepulcrale au fost

\footnotetext{
10 Pentru publicarea preliminară a obiectivului vezi Mihaela Simion et al., în CCA 2003 (2004), 160, 262-264.

${ }^{11}$ Cercetare efectuată de colectivul Muzeului Național de Istorie a României, București (18 complexe funerare).

12 Cercetare efectuată de colectivul Institutului de Arheologie „Vasile Pârvan”, Bucureşti (11 complexe funerare).

${ }^{13}$ Cercetare efectuată de colectivul Muzeului Național de Istorie a României, Bucureşti (cinci complexe funerare).
} 
săpate în stratul cu o consistență lutoasă, de culoare galbenă şi în roca nativă a dealului (în unele cazuri). Ele au formă rectangulară şi sunt orientate în general NV-SE. Sunt prezente ambele variante ale ritului incinerației: ardere pe loc (bustum) precum şi arderea la ustrinum. În cazul mormintelor busta se constată atât varianta clasică a mormântului rug (groapă rectangulară, de adâncime medie şi secțiune trapezoidală, cu urme consistente de arsură pe pereții interiori ai gropii şi în afara sa - şase morminte), cât şi cea complexă, a mormintelor cu groapa în trepte (cinci morminte).

În ceea ce priveşte celălalt obiectiv cercetat în punctul Jig-Piciorag acesta se află într-o stare de conservare precară, planul său fiind parțial reconstituit pe baza identificării a 11 aliniamente de pietre (Z1-Z11). Celelalte elemente constitutive ale structurii constructive constau într-o vatră-cuptor (V1) şi a două canale principale (C1-C2) cu diferite ramificații şi un bazinet de dimensiuni medii (B). La nord planimetria inițială a obiectivului este perturbată şi suprapusă de depuneri de reziduuri miniere din perioada modernă, iar la vest de un drum dezafectat, de asemenea, din perioada modernă (pl. 4, pl. 6/foto 2).

Perimetrul în care au putut fi identificate urme de exploatare minieră se întinde pe un spațiu de aproximativ 30/20 m fiind intersectat la sud şi la vest de necropolă. Z7, Z8, Z11, mai precis conturate şi păstrate pe înălțimea a două-trei asize, par să funcționeze ca ziduri exterioare ale acestei amenajări şi sunt grav afectate de intervențiile ulterioare. Construcția are dimensiunile de cса 8,00 $\times 23,00 \mathrm{~m}$, fiind orientată pe axa NNV-SSE. Nu avem nici un indiciu despre limita de sud a complexului, acesta fiind probabil o amenajare deschisă pe această latură. În interior, sunt vizibile cel puțin trei spații delimitate prezervate: Cam. 1 $(4,50 \times 2,00 \mathrm{~m})$, Cam. $2(2,50 \times 5,00 \mathrm{~m})$, Cam. $3(2,80 \times 3,00 \mathrm{~m})$. Forma lor neregulată şi sistemul constructiv primitiv sugerează mai degrabă delimitări de spațiu, în vederea unei utilizări particularizate, decât încăperi. Ipoteza este sprijinită de prezența canalelor, în conexiune cu traseele Z8, Z3 şi Z6, a bazinului $\mathbf{B}$ ca şi de prezența $\mathbf{V 1}$, care ocupă un spațiu central şi pare a deservi întregul complex. De asemenea, trebuie subliniată concentrarea pieselor destinate prelucrării primare a minereului în zona din imediata vecinătate a canalelor .

Vatra V1 (sau mai curând cuptorul) constă într-o structură din piatră semifasonată de formă circulară, cu un diametru exterior de 2,10 m. Ea fusese acoperită de dărâmătura blochetelor de piatră care au constituit elevația pereților. $\mathrm{Nu}$ s-a remarcat prezența nici unui fel de liant în amenajarea pereților. De remarcat prezența, în interior, a câtorva pietre care au suportat o arsură intensă, fiind impregnate cu o crustă roşiatică. În crusta de arsură erau vizibile o serie de mici amprente, probabil de la amplasarea şi fixarea creuzetelor (pl. 5, pl. 6/foto 3).

Canalul C1, poziționat în extremitatea de SE a amenajării, este orientat N-S. Are o lungime de aproximativ $5,50 \mathrm{~m}$, o lăţime de $0,15-0,20 \mathrm{~m}$ în extremitatea nordică, îngustându-se până la 0,07-0,08 m spre capătul sudic. Adâncimea sa maximă este de $0,30-0,35$ m. În extremitatea sudică pare să se dreneze într-un bazin, de asemenea amenajat prin săpare (B). Bazinul are o formă relativ rotundă, neregulată, cu dimensiunile de $3,77 \times 2,24 \mathrm{~m}$ şi o adâncime medie păstrată de cca. 1,20 m față de actualul nivel de călcare.

Canalul C2 apare sub stratul de cultură constituit din pământul negru afânat, la adâncimea de 0,62-0,68 m. Stânca în care a fost amenajat este puternic înroşită pe anumite porțiuni din traseul său, probabil în scopul unei exploatări facile. Canalul a fost surprins pe o lățime de 0,50-0,60 m până la adâncimea de 2,00 m şi este orientat N-S. Adâncimea maximă este în extremitatea de sud unde, de altfel, se lărgeşte.

Lipsa oricărui indiciu în ceea ce priveşte prezența unei elevații specifice sau a sistemului 
de acoperire indică utilizarea unor materiale de construcție cu un caracter perisabil. De asemenea, sărăcia materialului arheologic, redus în principal la artefacte legate de activitatea de prelucrare a minereului aurifer (mojare şi fragmente de mojare, fragmente de mese de măcinat sau nicovale etc.), indică, mai degrabă, o utilizare sezonieră a spaţiului, destul de redusă din punct de vedere cronologic.

În ceea ce privește datarea pe baza materialului arheologic singurul artefact care oferă anumite indicii este o monedă de argint, cu legenda Faustina Diva, recoltată din umplutura unei ramificații a canalului C1. Restul reperelor cronologice vor fi date de analiza exhaustivă a situației arheologice şi a materialului arheologic prelevat din zona funerară evidențiată în jumătatea de vest a proprietăţii Gomboş ${ }^{14}$. Cele câteva fragmente de ceramică aflate în conexiune stratigrafică $\mathrm{cu}$ funcționarea structurii constructive din punctul Jig-Piciorag se datează exclusiv in epocă romană.

Din punctul de vedere al cronologiei relative a utilizării spațiului supus investigației arheologice, trebuie făcută precizarea că, odată abandonată structura constructivă, jumătatea sa de est este reutilizată pentru necropola din imediata vecinătate. Această afirmație se bazează pe observațiile stratigrafice efectuate mai ales în ceea ce priveşte demontarea unei porțiuni din Z9 (şi deci anularea funcționalității Cam. 3) dar şi pe constatarea refolosirii, în amenajările exterioare a câtorva complexe funerare, a unor fragmente de artefacte legate de prima funcționalitate a structurii constructive.

\footnotetext{
${ }^{14}$ Existența unui spațiu dedicat exploatării miniere a determinat începutul unei colaborări cu dr. Beatrice Cauuet specialistă în arheologie minieră de la Universitatea din Toulouse, care a participat, începând din a doua jumătate a lunii august, la cercetarea de teren precum şi la prelevarea de probe în vederea realizării analizelor de laborator.
}

Astfel, din umplutura $\mathbf{M}^{15}$ a fost recuperat un fragment de gură de mojar (nr. Cat. 4) iar o serie de morminte (M1, M4, M18 $)^{16}$ au în componența amenajărilor de tip ring provenite de la piese de acest tip (mojare şi mese de măcinat sau nicovale de piatră fragmentare).

Este foarte dificil, având în vedere complexitatea cercetării arheologice într-un perimetru în care au fost identificate două obiective atât de diferite din punct de vedere funcțional, să oferim o imagine de ansamblu asupra întregii problematici legate de această situație. Totuşi, având în vedere stadiul

15 M3. Mormânt de incinerație, bustum cu groapa în
trepte, poziționat în C15, carourile $1-2 / c-e$, ad. $-0,50 \mathrm{~m}$.
Groapa, de formă rectangulară, este orientată NV-SE. Atât
pereții etajului superior cât şi cei inferiori prezintă urme
puternice de ardere. Dimensiuni groapă: $L=2,20 \mathrm{~m}, \mathrm{l}=$
$1,40 \mathrm{~m}$, ad. $=1,45-0,50 \mathrm{~m}$, ad. pe platformă $-0,25 \mathrm{~m}$.
Dimensiuni cameră de tiraj $-\mathrm{L}=1,20 \mathrm{~m}, \mathrm{l}=0,40 \mathrm{~m}$.
Resturi ale combustiei au fost descoperite atât pe
platformă, cât şi în partea inferioară a fosei. Oasele
calcinate au fost descoperite într-un strat compact de
cărbune, gros de $0,20 \mathrm{~m}$, fiind răspândite pe întreaga
suprafaţă a gropii de tiraj. A fost observată o intervenție
ulterioară. Inventarul păstrat a constat din: trei obiecte
de fier, o gemă, o monedă de bronz foarte corodată,
fragmente de la un opaiț.

${ }^{16}$ M1. Mormânt de incinerație, bustum, poziționat în C. 16 , carourile $1-3 / a-b$, ad. $=0,35 \mathrm{~m}$. Groapa, de formă rectangulară, trapezoidală în secțiune, cu pereții arşi, este orientată NV-SE. Dimensiuni groapă: L = 1,85 m, $\mathrm{l}=0,60 \mathrm{~m}$, ad. $=0,45 \mathrm{~m}$. Umplutura gropii este un lut de culoare galbenă. Stratul de cărbuni şi oase calcinate este răspândit pe toată suprafața gropii, în partea inferioară (grosime de 0,05-0,10 m). Dimensiuni ring: $\mathrm{L}=2,50 \mathrm{~m} ; \mathrm{l}=1,30 \mathrm{~m}$. A fost observată o intervenție ulterioară. Inventar prezervat: trei ulcioare, un opaiț; M4. Mormânt de incinerație, bustum, poziționat în C. 3, carourile $2-4 / \mathrm{a}-\mathrm{d}$, ad. $=0,43 \mathrm{~m}$. Groapa, de formă rectangulară, trapezoidală în secțiune, cu pereții arşi, este orientată VNV-ESE. Dimensiuni groapă: $\mathrm{L}=2,10$ $\mathrm{m}, \mathrm{l}=0,95 \mathrm{~m}$, ad. $=0,65 \mathrm{~m}$. Umplutura gropii este un lut de culoare galbenă. Stratul de cărbuni şi oase calcinate este răspândit pe toată suprafața gropii, în partea inferioară (grosime de 0,06-0,15 m). Dimensiuni ring: $L=2,40 \mathrm{~m} ; \mathrm{l}=1,35 \mathrm{~m}$. A fost observată $\mathrm{o}$ intervenție ulterioară. Inventar: două ulcioare, două opaițe; M18. Mormânt de incinerație, bustum, poziționat în C. 1., ad. = 0,50 m. Groapa, de formă rectangulară, trapezoidală în secțiune, cu pereții arşi, este orientată NV-SE. Dimensiuni groapă: $\mathrm{L}=1,50 \mathrm{~m}$, $\mathrm{l}=0,65 \mathrm{~m}$, ad. $=0,20 \mathrm{~m}$. Pământul de umplutură al gropii este un lut de culoare galbenă. Stratul de cărbuni, cenuşă şi oase calcinate este răspândit pe toată suprafața gropii, în partea inferioară, având grosimea de 0,10$0,15 \mathrm{~m}$. 
cercetării la aceste obiective, ne vom mărgini să facem o serie de considerații preliminare relative la funcționalitatea primei amenajări, pentru ca apoi să încercăm să schițăm câteva repere referitoare la conotația socioprofesională indusă de anumite aspecte ale sistemului de înmormântare din necropola de la Jig-Piciorag.

De asemenea, obiectele specifice acestei îndeletniciri, cu destul de dese semnalări în regiunea Patrulaterului Aurifer, nu au făcut, până în acest moment, obiectul publicării unui catalog unitar. Diverse astfel de artefacte au fost amintite sporadic, de cele mai multe ori fără a se specifica contextul descoperirii şi nici a se oferi o imagine sau desen a acestora. $\mathrm{Cu}$ atât mai puține sunt informaţiile despre aspectul şi caracteristicile tehnice ale acestor amenajări.

Informațiile referitoare la etapele de pregătire a minereului pentru faza finală, de transformare în lingouri, sunt oferite de două categorii de surse. Prima dintre acestea este constituită de mențiunile, în detaliu, provenite de la câțiva dintre autorii antici. Astfel, potrivit lui Plinius cel Bătrân ${ }^{17}$, operațiile primare de prelucrare constau în sfărâmarea, măcinarea, spălarea şi prăjirea (aglomerarea minereului). O sursă anterioară, Agathias ${ }^{18}$, preluată de Diodor ${ }^{19}$ (atunci când relatează despre exploatarea şi prelucrarea aurului în Egipt) menţionează doar trei dintre operații: zdrobirea, măcinarea şi spălarea auruluii ${ }^{20}$.

\footnotetext{
${ }^{17}$ Plinius, 33, 60, 69, 99.

18 Agathias (sau Agathius sau Agatharchides) "Grecul" (181-146 a.Chr.)

${ }^{19}$ Diodor, III, 13, 14.

${ }^{20}$ Informație confirmată de situația constatată pentru prelucrarea primară a mineralelor bogate în aur nativ. Astfel, etapa imediat premergătoare extracției şi zdrobirii era măcinarea; Cauuet 2004, p. 70-71. De asemenea, referitor la situația descrisă de autorii antici în Egiptul antic, cercetările arheologice au confirmat aproape în totalitate procedeele tehnologice descrise de autorii mai sus citați. Exemplul cel mai semnificativ este dat de cercetarea sitului minier de la Bir Umm Fawakhir, chiar dacă majoritatea urmelor prezervate se datează în perioada bizantină timpurie; vezi Meyer 1997, p. 64-68.
}

În acelaşi timp, cercetarea arheologică a regiunilor miniere din Spania, Portugalia şi Franța a oferit, pe baza informațiilor colectate din diverse situri arheologice, o imagine destul de completă despre procedeul tehnologic al prelucrării minereului aurifer. Astfel, prima operație, consta în sfărâmarea minereului extras şi alegerea materialului cu potențial de extracție. Această operație are loc în interiorul abatajului, a minei propriuzise sau în imediata apropiere a locului de extracție $^{21}$. Etapa imediat următoare este legată de existența atelierelor primare. Exemple de asemenea ateliere sunt înregistrate la: San Pablo, Valderrepiso, La Dehesa, La Gargantilla, etc $^{22}$. Amplasamentele acestora diferă: unele sunt poziționate în imediata apropiere a locului de exploatare, iar altele pe colinele din vecinătatea exploatărilor (cazul celor din zona Atalaya ${ }^{23}$ ).

Această variație a amplasamentelor precum şi cea a poziţionării atelierelor metalurgice trădează preocuparea tehnicienilor romani pentru a instala aceste amenajări în locuri cât mai propice. De cele mai multe ori, ele se află la oarecare distanță de aşezări dat fiind faptul că de obicei reziduurile degajate sunt toxice ${ }^{24}$. Se remarcă faptul că, de cele mai multe ori, aceste ateliere ocupă poziții dominante, legate de prezența versanților, bine amplasate față de direcția vânturilor şi în apropierea unei surse de apă ${ }^{25}$.

Este evidentă legătura ansamblului cercetat de noi cu prelucrarea primară a minereului aurifer. $\mathrm{O}$ serie de elemente evidenţiate în cazul sitului Jig-Piciorag sunt

\footnotetext{
${ }^{21}$ Urme de separare şi zdrobire a minereului imediat după extracție au fost puse în evidență în interiorul galeriilor şi în imediata vecinătate a exploatărilor miniere antice de la Serra de Santa Justa, Sortijón del Cuzna etc. cf. Domergue 1990, 496; Pl. XXVIIIa.

${ }^{22}$ Domergue 1990, 495.

${ }^{23}$ Domergue 1990, 369-371.

${ }^{24}$ Domergue 1990, 496.

${ }^{25}$ Din acest punct de vedere este semnificativă situația descrisă pentru ansamblul minier de la Loba (Fuenteobejuna, provincia Cordoba, Spania); vezi Domergue, Sillères 2002, 85-162.
} 
în directă relație cu procesul tehnologic specific acestei activități.

O atenție particulară, din punctul de vedere al posibilei funcționalități, o prezintă sistemul de canale cercetat în această zonă. Metoda consta în realizarea de canale înclinate, deschise, în zăcământul prezent la suprafață, prin care trecea un debit moderat de apă care antrenează materialul, îl dezagregă şi îl separă preliminar de impurităţi.

Astfel s-ar explica succesiunea de canale şi gropi de o formă neregulată care utilizează panta naturală în maniera drenării apelor naturale pe versant. În general sunt şantiere de mici dimensiuni şi sunt dependente de existența ori a aducțiunii de apă sau a unor bazinete de exploatare. Majoritatea elementelor evidențiate în zona Jig-Piciorag ar putea sugera, cel puțin pentru prima fază a ocupării spațiului, această funcționalitate ${ }^{26}$.

Despre acest tip de exploatare sursele antice sunt destul de ambigue. Este cunoscută clasificarea pe care Plinius o face între două tipuri de zăcăminte aurifere. Astfel, acest autor antic face diferența între aurul din nisipuri aluvionare auriferae arenae (zone cu bogata concentrație), pepite aurifere exploatate din zona aluvionară (ramenae) şi aurul extras din rocă (aurum canaliense) ${ }^{27}$. O informație de la Strabon specifică faptul că, în anumite regiuni, aurul filonian ar fi jucat un loc secundar ${ }^{28}$. În acelaşi timp, Diodor afirmă că metalul prețios se extrăgea inclusiv din structuri cuarțitice aflorate la suprafață ${ }^{29}$,

\footnotetext{
${ }^{26} \mathrm{Cu}$ rezervele de rigoare, conferite de dimensiunile analogiilor citate, semnificative sunt cazurile de la Valduerna, Reguera de Las Fuentes, Manzanal del Puerto, Manzarnoso şi Sanfitorio; cf. Domergue 1990, p. 464-465. De asemenea, deşi la o scară mult mai extinsă, având în vedere caracterul aluvionar (detritic) al zăcământului este situația constatată în N-V Spaniei (Cota Valleador) în special exploatările din regiunea Leon; cf. Sanchez - Palencia Ramos 1979, 53, fig. 18.

${ }^{27}$ cf. Domergue 1990, 26, n. 9; pl. 33, 66.

${ }^{28}$ Strabon, III, 2, 8.

${ }^{29}$ Diodor, III, 12.
}

care, în opinia anumitor autori ${ }^{30}$, se identifică $\mathrm{cu}$ ceea ce Plinius denumea aurum canalicium sau canaliense marmoris glareae inhaerens ori cu metoda de exploatare din Spania - aşa-numitele arrugiae $^{31}$. După opinia lui Claude Domergue, în aceste pasaje autorul antic face o distincție destul de clară referindu-se la tipul de zăcământ şi mai puțin la tehnica de exploatare cum facil ar putea fi tradus etimologic textul ${ }^{32}$. Indiferent de interpretarea sau de nuanțele termenului, este vorba despre zăcământul extras din rocă şi nu de exploatările de zăcăminte de tip detritic.

În sprijinul ipotezei potrivit căreia zona de la Jig-Piciorag poate să fi fost inițial o zonă de extracție a unui zăcământ la suprafață sunt o serie de elemente constatate în cazul celor două canale principale (C1şi C2), a ramificațiilor acestora, precum şi caracteristicile stratigrafice ale zonei imediat învecinate. Astfel, urmele de tratament termic ale rocii din care s-a făcut extracția corespund unui procedeu tehnologic uzitat în epocă, şi anume încălzirii rocii pentru o mai uşoară dislocare $^{33}$. Apoi, relativa suprapunere a nivelului de construcție a traseelor de zid față de amenajarea canalelor ar fi un indiciu pentru a considera prima faza a ocupării spațiului în funcție de un posibil punct de exploatare, cu caracter limitat şi fără investiții economice deosebite (probabil legat de o inițiativă particulară restrânsă).

În ceea ce priveşte descoperirea in situ sau în nivelul de dărâmătură corespunzător amenajării constructive din punctul JigPiciorag a unui număr însemnat de artefacte utilizate în cadrul procesului tehnologic de prelucrare primară a zăcământului aurifer, descris mai sus, aceasta indică prezența - la un moment dat - pe acelaşi amplasament, a unui atelier (fonderie) tipic pentru epoca romană. Nu trebuie exclusă, în eventualitatea confirmării ipotezei punctului de extracție, o

\footnotetext{
${ }^{30}$ Wollmann 1996, 120-121.

${ }^{31}$ Plinius, 33, 70.

32 cf. Domergue 1990, 26-27.

${ }^{33}$ Cauuet et alii 2003, 475, 478.
} 
reutilizare a sistemului de canale pentru procedeul tehnologic al spălării minereului. Asocierea dintre sistemul de canale și prezența mojarelor şi a meselor de măcinat, precum şi caracteristicile constructive ale structurii de combustie denumite de noi convențional (în timpul cercetării) V1, pare să confirme această afirmație. Analogiile nu lipsesc în diverse zone miniere cercetate arheologic. Este cazul situației constatate, în siturile miniere datate în epocă romană de la Serra de Santa Justa ${ }^{34}$, Rio Tinto ${ }^{35}$, La Gargantilla $^{36}$ etc.

O atenție particulară o suscită, din punctul de vedere al caracteristicilor sitului investigat de noi, o serie de descoperiri din regiunea Limousin (Franța) $)^{37}$. Chiar dacă aceste descoperiri sunt datate în perioada preromană, ele sunt foarte sugestive, având în vedere că tehnica de prelucrare primară a minereului aurifer se bazează pe principii arhetipale simple, păstrate până în pragul „revoluției industriale” ${ }^{38}$. Un sit cu caracteristici asemănătoare este cel de la Puy des Angles, cu o funcționalitate, potrivit autorilor cercetării, de atelier şi spălătorie de aur $^{39}$. De asemenea, amenajări cu caracteristici similare au fost cercetate în

\footnotetext{
${ }^{34}$ Domergue 1990, 126.

${ }^{35}$ Domergue 1990, 497.

${ }^{36}$ Domergue 1990, 498.

37 Pentru întreaga problematică, foarte complexă, a acestor situri miniere vezi: Sagui 1940, 250-277; Laporte 1965a, 45-78; Laporte 1965b, 23-111; Cauuet 1995, 33 - 42; Cauuet 2004.

38 Informațiile oferite de o serie de autori antici, referitoare la aceste probleme (Agatarghides, Diodor, Dioskourides, Pliniu, etc) nu diferă foarte mult în ceea ce priveşte tehnologia de prelucrare primară de cele provenite din izvoare ceva mai târzii. Astfel, în perioada bizantină, o serie de autori vorbesc despre existenta unor ateliere de procesare (purificare) a zăcământului aurifer, descriind o tehnologie aproape identică cu cea înregistrată la autorii antici. Vezi: Nicetae Choniatae Historia, 347; Halleux 1985, p. 3977; Matschke 2002, 119. De asemenea, G. Agricola, De re Metallica, XII.

39 Situl este datat în perioada preromană, în secolele III-II a. Chr. cf. Toledo I Mur A, Le Puy des Angles (Les Angles-sur-Corrèze, 19): une mine d'or Protohistorique, Limoges, 2002 (apud Cauuet 2004, 70-76).
}

legătură cu exploatările de aur de la Foilloux $^{40}$, Cros Gallet-nord ${ }^{41}$ şi Cros Gallet$\operatorname{sud}^{42}$.

În afara analogiilor de mai sus, a sistemului de canale descoperit la Jig în conexiune cu anumite lărgiri ale acestora, care pot fi interpretate ca bazine, situația arheologică nu a înregistrat nici un artefact care să sugereze clar existenta unei spălătorii. Ipoteza este însă tentantă dacă sunt conectate toate elementele descoperite in situ. Lipsa artefactelor specifice spălătoriilor artizanale se explică, credem noi, prin confecționarea acestora din materiale foarte perisabile. Relativ însă la modalitatea de realizare a canalelor şi la maniera de adaptare a acestora la panta naturală uşoară nu trebuie trecută cu vederea una din informațiile conținute în des invocata operă a lui Plinius. Potrivit textului antic, spălarea, în cazul existenței instalațiilor fixe ${ }^{43}$ se realiza, în cazul unui atelier de mici dimensiuni, prin practicarea unui sistem de canale direct în sol (agogae ${ }^{44}$. Pudra auriferă era amestecată cu apa şi vărsată în micile canale amenajate în plan înclinat care se drenau într-un bazinet terminal. Şanțurile erau căptuşite cu stofă de lână, piei de oaie sau tufe de rozmarin, astfel încât pulberea de aur să fie reținută ${ }^{45}$.

\footnotetext{
${ }^{40}$ Cauuet 1988, 181-190.

${ }^{41}$ Cauuet 1993, 41-42; Cauuet 1994, 42-44.

${ }^{42}$ Cauuet 1994, 42-44; Cauuet 2004, 70-76.

43 Principala tipologie a amenajărilor pentru spălarea minereului este distincția între "instrumente portabile" şi "instalațiile fixe”. Această diferențiere este surprinsă şi de o serie de texte antice. Astfel, relativ la „instrumentele portabile" din lemn Plinius utilizează diverse formulări: calathi (sau catilli) ori alueus, toate desemnând ustensile din lemn sau piele utilizate pentru separare/cernere cu ajutorul apei (troc, coş suspendat şi apoi scufundat în apă, sistem de site, etc.). Indiferent de via dispută la nivel etimologic referitoare la traducerea exactă a funcționalității acestor obiecte, ele sunt menționate ca fiind utilizate în operațiunea de spălare a diverselor minerale, cu o frecvență mai mare la metalele neferoase. Cf. Plinius, 33, 67; 34, 157. Pentru întreaga discuție referitoare la interpretările termenilor utilizaţi vezi: Ramin 1977, 110-111; Domergue 1990, 500-501.

${ }^{44}$ Plinius, 33, 76.

${ }^{45}$ Cauuet 2004, 72-73.
} 
Unul dintre elementele definitorii ale unei arii dedicate acestui tip de activitate este prezența structurilor de combustie necesare pentru procedeul tehnologic al fuziunii şi al rafinării minereului. Astfel, concentratul aurifer obținut în urma operațiunii de spălare conține încă o serie întreagă de impurități (siliciu şi alte particule de minerale grele). Praful de minereu obținut trebuie să fie încălzit într-un creuzet refractar pentru a fi curățat de impurități. Informațiile referitoare la acest procedeu sunt destul de clare la autorii antici preocupați de problemă. Există, din acest punct de vedere, două teorii diferite, referitoare la temperatura de topire care trebuia dezvoltată de o asemenea structură. Astfel, Agatarchides şi implicit Diodor ${ }^{46}$ descriu în timpul procedeului de topire, un foc de intensitate mare, în care creuzetele se țineau cinci zile (recipientele în care se realiza rafinarea sunt denumite aggo $\beta$ kerameo $3 / 4 n$ ), în timp ce Hypocrate ${ }^{47}$, Stabon $^{48}$ şi Plinius ${ }^{49}$ vorbesc despre o temperatură moderată şi constantă, obținută cu pleavă, pentru a împiedica volatilizarea produsului. Aceste din urmă relatări sunt confirmate atât de caracteristicile fizico chimice ale metalului supus rafinării ${ }^{50}$, cât şi de rezultatele oferite de o serie de studii de arheologie minieră experimentală ${ }^{51}$.

Pentru o asemenea funcționalitate pledează prezența structurii de combustie, denumită de noi V1, amplasată în poziție

\footnotetext{
${ }^{46}$ Diodorus, III, 14. Foloseşte pentru descrierea acestor recipiente, pe care le menționează ca introduse într-un cuptor, termenul de kerameìß kutroi.

${ }^{47}$ De vict. rat. I.

${ }^{48}$ Geographia, III, 2, 8.

${ }^{49}$ Plinius, 33, 60, 69. Plinius foloseşte, pentru a descrie recipientul refractar, în care se realiza fuziunea şi rafinarea, termenul de catina.

${ }^{50}$ Halleux 1985, 39-77; Cauuet, Tollon 1999, 185-198.

${ }^{51}$ Cauuet 2004, 105-112. Mai mult, o serie de artefacte, ca de exemplu creuzetele aflate în Muzeul Etnografic Lupşa, jud. Alba, nu poartă urmele unei arderi secundare de mare intensitate (cf. Wollmann 1996, 122). De asemenea, pentru diverse elemente referitoare la informațiile despre prelucrarea aurului în bibliografia istorico-arheologică românească de specialitate vezi şi: RE Supp.IV, col. 152 sqq (Orth); Christescu 1926, 22; Daicoviciu 1945, 134 sqq.
}

centrală în cadrul amenajării de la JigPiciorag. $\mathrm{Cu}$ dimensiuni şi amplasament asemănătoare situației surprinse de noi este şi cea din cazul sitului Fouilloux ${ }^{52}$. Instalații pe acelaşi principiu sunt bine cunoscute în principalele situri miniere de epocă romană, numai că, spre deosebire de tot ansamblul de la Jig-Piciorag, care pare să aibă un caracter „artizanal”, fiind o întreprindere restrânsă, cele cercetate la Coto Fortuna $^{53}$, El Robledo $^{54}$ şi San Pedro ${ }^{55}$, sunt legate de exploatări miniere pe scară largă şi sunt grupate în adevărate „zone industriale metalurgice" 56 . $\mathrm{Cu}$ caracteristici mai apropiate de cazurile analizate în studiul de față sunt cele de la La Gargantilla ${ }^{57}$, Tharsis $^{58}$, Santa Rosa ${ }^{59}$, dar şi ele legate de marea exploatare minieră.

În ceea ce priveşte prezența artefactelor specifice unei asemenea structuri (creuzete, fragmente de creuzete, mici concrețiuni de

\footnotetext{
${ }^{52}$ Vatra sau cuptorul de la Fouilloux are caracteristici similare cu V1. Forma sa este relativ rectangulară pe exterior, pentru ca în interior să aibă tendinţa de uşoară rotunjire. Dimensiunile sale sunt relativ reduse, de 0,70 $\times 0,80$. Similar cazului V1, a fost descoperită suprapusă de dărâmătura pereților (de chirpic, spre deosebire de V1 unde dărâmătura consta în blochete de piatră). Şi în acest caz, autorii cercetării consideră că funcționalitatea acestui complex este legată de o amenajare ,artizanală” în conexiune cu procesul de fuziune şi rafinare a minereului aurifer (cf. Cauuet 2004, 76-77).

${ }^{53}$ Cuptoare cilindrice, din piatră legată cu mortar, cu un diametru interior de cca. 0,80 m şi o înălţime păstrată a pereților de cca. 0,90 m (cf. Domergue 1990, 504).

${ }_{54}$ Domergue 1990, 504.

${ }^{55}$ Domergue 1990, 504.

56 În general, toate aceste structuri, datate în principal în epocă romană republicană dar fiind în uz şi în secolele I şi II p.Chr., beneficiau de instalații conexe elaborate, erau acoperite şi se constituiau în structuri obişnuite pentru fuziunea galenei, indiferent de metalul prelucrat (cf. Forbes 1958, 70-80).

57 Aceste amenajări fac parte din aşa numita serie tipologică "bowl furnace" fiind reduse la amenajări simple în sol, sau la suprafața solului. Pentru întreaga tipologie realizată în general în cadrul bibliografiei anglo saxone de specialitate, vezi Forbes 1950, 70-80; Haley 1978, 153; Domergue 1990, 503-506.

${ }^{58}$ Gonzalo y Tarin 1888, 40.

${ }^{59}$ Davies 1935, 46
} 
cuarț vitrifiat) suntem în posesia câtorva exemplare, deocamdată în curs de analiză ${ }^{60}$.

Din toate elementele analizate pe parcursul studiului de față se distinge, ca o primă concluzie, că, în cazul structurii constructive de la Jig-Piciorag există elemente care să fundamenteze ipoteza atribuirii funcționalității de atelier de prelucrare primară. Astfel, sfărâmarea şi măcinarea este documentată prin prezența, în imediata vecinătate a sistemului de canale (mai ales în Cam. 1), a unui număr însemnat de mojare şi mese de măcinat (pl. 6/foto 4).

Asemenea cazuri sunt înregistrate practic în cadrul majorității siturilor miniere cercetate. Deşi inițial aceste piese arheologice au fost legate de exploatări preistorice ${ }^{61}$, prezența lor persistă însă datorită formulei lor arhetipale simple o lungă perioadă de timp, fiind în funcție inclusiv în perioada bizantină $^{62}$. De asemenea, ele funcționează şi ca nicovale, multe dintre ele fiind descoperite în apropierea structurilor de combustie.

Cealaltă categorie de artefacte specifică atelierelor de procesare este cea constituită din mojarele de piatră. În stadiul actual al cercetării noastre putem indica o

${ }^{60}$ Analizele complexe ale acestor elemente sunt în curs de efectuare în cadrul laboratoarelor UTAH, Université

| Toulouse Le Mirail, prin bunăvoința doamnei Beatrice Cauuet, căreia îi mulțumim încă odată. Un catalog complet precum şi studiile interdisciplinare referitoare la caracteristicile minereului prelucrat în zona JigPiciorag vor face parte din preconizata publicare monografică a obiectivului în cadrul seriei monografice Alburnus Maior.

${ }^{61}$ Frecvente în cazul exploatărilor timpurii de cupru din Austria (Pittioni 1958, 34, fig. 13), în nordul Africii (Rothemberg 1972, pl. 21, 23, 24), Olanda, Rusia, Irlanda etc. (un catalog al celor mai importante descoperiri de acest tip la Butler, Van der Waals 1966, 63-73), Franța (Cauuet 2004, 71) etc.

62 În siturile miniere de epocă romană ele sunt foarte frecvente, mai ales în cazul unor mici exploatări de pe lângă exploatarea pe scară industrială. Ex.: Trâs Minas, Pozos dans le Telano, Nava Ricomalillo, La Loba etc. (Peninsula Iberică); Martys-Aude (Franța) cf. Domergue 1990, 125; La Loba (Fuenteobejuna, Cordoue, Espagne); Blázquez, Domergue 2002, 371373, fig. 187/ 1, 2. Pentru epoca bizantină sunt atestate în număr considerabil în cadrul exploatării aurifere de la Bir Umm Fawakhir. Meyer 1997, 64-68; Matschke 2002, 120. apropiere tipologică a mojarelor din punctul Jig Piciorag mai degrabă cu cele descoperite în zona exploatărilor miniere de la Laurion ${ }^{63}$ decât in zonele miniere occidentale ${ }^{64}$.

Prezența meselor de măcinat sau a nicovalelor de dimensiuni mici, precum şi a mojarelor prin care se realiza măcinarea fină şi nu a morilor de piatră sau a altor instalații de concasare elaborate, se poate explica, din nou, prin acelaşi caracter restrâns al prelucrării.

O singură verigă din lanțul tehnologic propriu prelucrării acestui metal nu se regăseşte în situația arheologică constatată în acest punct. Este vorba despre existența aşa numitelor zone de ardere (arii de ardere). Lipsa zonelor dedicate tratamentului termic primar al minereului poate fi explicată prin caracteristicile fizico-chimice ale zăcământului aurifer din zona Roşia Montană ${ }^{65}$. Astfel, este vorba de un minereu cu un conținut scăzut de sulfuri poate cu caracteristici apropiate de cel exploatat în antichitate în Egipt. Despre acest din urmă zăcământ Diodor ${ }^{66}$, folosind sursa Agatarchides, vorbeşte despre existența doar a trei operații: zdrobirea, măcinarea şi spălarea aurului. De asemenea, în cazul zăcămintelor exploatate în minele din nord-vestul Peninsulei

\footnotetext{
63 Ardaillon 1897, 61, fig. 18; Photiades, Morin 2005, 327-258.

${ }^{64}$ De altfel Diodor (III, 13, 1), preluând informația de la Agatatchides, menționează utilizarea acestei metode de mărunțire a minereului pentru exploatările miniere din Egipt folosind pentru astfel de artefacte termenul de tImoi liqínoi. În siturile miniere occidentale mojarele de piatră sunt mai puțin întâlnite (ex. Rio Tinto), poate datorită durității rocii supuse procesării. De aceea, pentru aceste situri, sfărâmarea şi mărunțirea se realiza prin intermediul unor instalații ceva mai elaborate (moară sau adevărate cavități amenajate în rocă în care pisarea se făcea prin intermediul unor instalații cu scripete). cf. Domergue 1990, 498-500, fig. 46c.

${ }^{65}$ Zăcământul epitermal de aur şi argint de la Roşia Montană este unul de tip adular-sericit (low sulfidation). În cadrul zăcământului, pe lângă structura de brecie de Cetate (un corp de minereuri cu conținuturi de aur deosebite) există şi alte tipuri de corpuri de minereu: filoane, stokwerk-uri, impregnații, brecii, placersuri şi paloplacersuri (aluviuni) (cf. Cauuet et alii 2003, 473).

${ }^{66}$ Diodor, III, 13, 14
} 
Iberice, nivelul diseminării conținutului de metal este atât de ridicat încât nu este nevoie de aglomerarea minereului fiind suficientă spălarea imediat după o mărunţire foarte fină ${ }^{67}$. Tratamentul termic se utilizează în cazul mineralelor foarte complexe, foarte sulfurate ${ }^{68}$.

Toate aceste elemente, analizate parțial în studiul de față, credem că ne îndreptățesc să atribuim unei părți din perimetrul cercetat în zona Jig-Piciorag o funcționalitate de atelier de procesare primară a zăcământului aurifer. Rezultatele analizelor de laborator ${ }^{69}$, acum parțial disponibile, vor aduce noi clarificări referitoare la modalitățile efective de realizare a procesării, precum şi la o serie de caracteristici fizico-chimice ale minereului preparat aici în epocă romană.

Pentru atribuirea funcționalității pe care am propus-o pledează şi analiza preliminară a materialului arheologic provenind din structura analizată. Este vizibilă o delimitare funcțională a materialului arheologic provenit din interiorul zonei de prelucrare față de cel din interiorul necropolei de incinerație din vecinătate. Astfel, se constată o pondere redusă a inventarului cu posibilă funcționalitate funerară, în comparație cu funcționalitate uzuală.

\section{A. Ceramica}

Materialul ceramic descoperit în structura constructivă de la Jig-Piciorag este destul de bine reprezentat, din punct de vedere cantitativ, fiind identificate un număr de 78 de piese, în totalitate fragmentare. Studiul ceramic a luat în considerare întregul lot de material.

Urcioare $(\text { urceus })^{70}$ - au fost catalogate cinci exemplare (nr. cat. 20, 70, $71,79,88$ ), a căror stare de conservare este precară, doar o piesă putând fi reconstituită ca formă (nr. cat. 79). Aceasta împreună cu

\footnotetext{
${ }^{67}$ Domergue 1990, 500, n.17.

${ }^{68}$ Cauuet 2004, 70-71.

69 Buletinele de analiză, în curs de prelucrare, vor face obiectul unei publicări integrale în viitoarea monografie dedicată acestui sit.

${ }^{70}$ Hilgers 1969, $83-86$.
}

piesa nr. cat. 70 se înscriu în categoria urcioarelor care imită vasele din bronz. Buza înălțată vertical, rotunjită, cu o profilatură externă puternic pronunțată. Gât scurt şi larg. Corp ovoidal. Baza dreaptă. Este prevăzut cu o toartă canelată, ataşată sub buză şi deasupra diametrului maxim. Hilgers consideră acest tip ca recipient pentru stocarea vinului şi a apei $^{71}$. Cunoscută îndeosebi în aşezările din Dacia Superior ${ }^{72}$ şi $^{73}$ Moesia Inferior, piesa este întâlnită mai rar şi în necropolele de la Roşia Montană (necropolele de la $\operatorname{Hop}^{74}$ şi Tăul Cornei ${ }^{75}$ ).

Celelalte trei recipiente sunt fragmentare, constând într-un fragment de bază (nr. cat. 88), respectiv fragmente din corp (nr. cat. 20, 71), ceea ce nu a permis încadrarea tipologică a acestora. Un singur urcior a fost descoperit în interiorul structurii constructive (nr. cat. 20), restul provenind din exteriorul acesteia.

Dolia $^{76}$ - categorie de vase reprezentată prin două piese (nr. cat. 50, 72), descoperite în exteriorul structurii constructive, dar este foarte mare probabilitatea ca acestea să fi fost folosite în cadrul operațiilor efectuate în interior, fiind rulate. Din ambele exemplare au fost recoltate doar fragmente din buză cu corp. Aceste vase sunt caracterizate prin buza lată, rotunjită, îngroşată, înclinată spre exterior până la orizontală. Pereți groşi. Piesa cu nr. cat. 72 este puternic arsă secundar, situație ce ne permite să intuim funcționalitatea acestui tip de obiecte ceramice. Dată fiind funcționalitatea structurii constructive putem deduce că piesele au fost utilizate în cadrul unor operaţiuni ce au determinat intrarea în contact a acestora cu anumite structuri de combustie. Pasta semifină, cu incluziuni de cuarț alb şi cenuşiu, oxizi de fier, pirită şi rare paiete fine

\footnotetext{
${ }^{71}$ Hilgers 1969, 83.

72 Popilian 1976, 188, nr. 459, pl. XLIII/459, la Romula.

73 Suceveanu 2000, 153, nr. 17, pl. 72/17, la Histria.

${ }^{74}$ Moga et alii 2003, 241, fig. 27/16.

75 Alburnus Maior III (sub tipar).

${ }^{76}$ Hilgers 1969, $171-186$.
} 
de mică, trădează originea locală a acestor vase. Piesele îşi găsesc analogii la Roşia Montană, în structurile de habitat de la Tăul Țapului $^{77}$, dar şi în Moesia Superior ${ }^{78}$.

Mortaria - categorie ceramică des întâlnită la trupele romane din castre ${ }^{79}$, dar şi în aşezările civile. Au fost recoltate două exemplare (nr. cat. 76, 80), (fragmente de buze cu corp). Dar funcționalitatea acestor piese în situația de aici pare să fi fost cu totul alta, şi anume aceea de a măcina în ele anumite elemente. Acestea se caracterizează prin marginea buzei lată, decorată cu două caneluri, rotunjită, înclinată spre exterior până la orizontală, la unul din capete având un deversor, care nu s-a păstrat la nici una dintre piese. Exemplare asemănătoare ca formă sunt semnalate în Dacia Superior (la Ampelum, unde este cunoscută existența unui atelier de mortaria ${ }^{80}$ şi la Romula ${ }^{81}$, Pannonia Inferior (la Sirmium ${ }^{82}$ ) şi în Moesia Inferior (la Durostorum ${ }^{83}$ ). Nu este exclus ca aceste exemplare să provină din atelierele de Ampelum.

Turibula - categorie reprezentată printrun singur exemplar (nr. cat. 60), din care se păstrează un fragment de buză cu corp. Vasul este caracterizat prin buza arcuită, uşor înclinată spre exterior, decorată cu alveole mari, realizate prin presarea cu degetele a celor două margini (superioară şi inferioară) când pasta era crudă. Acest tip de vase este utilizat în special în cadrul ceremonialului de înmormântare în anumite secvențe ${ }^{84}$, de aceea este foarte posibil ca acest vas să provină din inventarul unui mormânt. Această afirmație este sprijinită de faptul că piesa prezintă urme de ardere secundară. Piesa are analogii la Roşia Montană (în

\footnotetext{
77 Damian et alii 2003, 118, fig. 26/27.

${ }^{78}$ Brukner 1981, 96, nr. 112, pl. 89/112.

${ }^{79}$ Hilgers 1969, 58.

${ }^{80}$ Băluță 1981, 264.

${ }^{81}$ Popilian 1976, 172, nr. 214, pl. XVII/214.

${ }^{82}$ Brukner 1981, 83, nr. 3, pl. 60/3.

${ }^{83}$ Mușețeanu 2003, 114, nr. 83.

${ }^{84}$ Hilgers 1969, 294-295.
}

necropola de la $\operatorname{Hop}^{85}$ şi în inventarul monumentului funerar circular din punctul Basil Cosma ${ }^{86}$ ), dar şi în unele aşezări din Dacia Superior (la Stolniceni ${ }^{87}$ ).

Oale (aula sau olla) $)^{88}$. Au fost descoperite 48 de exemplare din această categorie de obiecte în totalitate fragmentare. Dintre acestea, nouă au fost recoltate din interiorul structurii constructive (nr. cat. 3-6, 9, 11, 14-15, 21). $\mathrm{Cu}$ mare dificultate, datorită indicelui mare de fragmente, au fost distinse mai multe tipuri de oale:

Un prim tip, reprezentat de zece exemplare (nr. cat. 14-15, 24, 27, 42, 44, 5152, 61, 83), este caracterizat prin buza înălțată vertical, uşor rotunjită, cu şănțuire internă pentru capac. Corp globular, cu diametrul maxim în partea superioară. Baza dreaptă. Un singur exemplar (nr. cat. 42) a putut fi reconstituit în totalitate ca tip. Acesta îşi găseşte analogii la Roşia Montană ${ }^{89}$, în Dacia Superior (la Locusteni ${ }^{90}$ ), în Pannonia Inferior (la Mursa $^{91}$ ) şi în Moesia Inferior (la Durostorum $^{92}$ ).

Un al doilea tip, reprezentat de nouă exemplare (nr. cat. 3, 11, 26, 28, 67, 77, 78, 81, 89), este caracterizat prin buza rotunjită, îngroşată, uşor înclinată spre exterior. Corp globular, în unele cazuri, decorat cu incizii. Baza dreaptă. Aceste piese au analogii la Roşia Montană, în structura de habitat de la Tăul Țapului ${ }^{93}$, în Dacia Inferior (la Drobeta $^{94}$ ) şi în Moesia Inferior (la Histria $^{95}$ ).

Al treilea tip de oale, reprezentat de două exemplare (nr. cat. 25, 45), se caracterizează prin buza rotunjită, îngroşată,

\footnotetext{
${ }^{85}$ Moga et alii 2003, 240, fig. 26/1.

${ }^{86}$ Simion et alii 2004, 62, nr. 6, pl. 39/6.

${ }^{87}$ Popilian 1976, 208, nr. 753, pl. LXII/753.

${ }^{88}$ Hilgers 1969, 39-40.

${ }^{89}$ Rusu-Bolindeț et alii 2003, 327, nr. 52, fig. 23/52.

90 Popilian 1976, 180, nr. 333, pl. XXXIV/333.

${ }^{91}$ Brukner 1981, 105, nr. 59, pl. 114/59.

92 Mușețeanu 2003, pl. 38/46.

${ }^{93}$ Damian et alii 2003, 93, nr. 11, fig. 22/11.

${ }^{94}$ Popilian 1976, 182, nr. 369, pl. XXXVI/369.

${ }^{95}$ Suceveanu 2000, 112, nr. 1, pl. 47/1
} 
triunghiulară în secțiune, uşor înclinată spre exterior. Acest tip îşi găseşte analogii în Pannonia Inferior (la Mursa ${ }^{96}$ ) şi în Moesia Superior (la Singidunum ${ }^{97}$ ).

Un al patrulea tip este reprezentat printr-un exemplar (nr. cat. 82), caracterizat prin buza îngroşată, rotunjită, uşor înclinată în interior, cu şănţuire internă pentru capac. Acest tip are analogii la Roşia Montană, în structura de habitat de la Tăul Țapului ${ }^{98}$, la Durostorum $^{99}$ şi la Singidunum ${ }^{100}$.

Al cincilea tip de oale este reprezentat prin două exemplare (nr. cat. 43, 46), constituit de piese miniaturale, prevăzute cu buza înălțată vertical, rotunjită, cu şănţuire internă pentru capac. Corp globular. Baza dreaptă. Sunt prevăzute cu o toartă canelată, ataşată sub buză şi pe diametrul maxim. Piesele din acest tip au analogii în Dacia Superior (la Romula ${ }^{101}$ ), Moesia Inferior (la Durostorum ${ }^{102}$ ) şi în Moesia Superior (la Singidunum ${ }^{103}$ ).

Trebuie menționat faptul că 24 de piese incluse în acest catalog nu au putut fi încadrate tipologic, datorită gradului mare de fragmente, din acestea parvenindu-ne numai fragmente din corp.

Cupe. $\mathrm{Au}$ fost recoltate patru exemplare (nr. ca. 48, 84, 73, 87), în totalitate fragmentare, doar una putând fi reconstituită ca tip. Se caracterizează prin buza rotunjită, înălțată vertical. Corp globular. Baza inelară. Este prevăzută cu o toartă necanelată, ataşată pe buză şi pe diametrul maxim. Îşi găseşte analogii la Roşia Montană ${ }^{104}$, în Dacia Superior (la Romula ${ }^{105}$ ), în Moesia Inferior

\footnotetext{
${ }^{96}$ Brukner 1981, 105, nr. 59, pl. 114/59.

${ }^{97}$ Nicolić-Dordević 2000, 81, tipII/39.

${ }^{98}$ Damian et alii 2003, 112, fig. 20/1.

${ }^{99}$ Muşețeanu 2003, pl. 36/18.

${ }^{100}$ Nicolić-Dordević 2000, 66, tip II/1.

${ }^{101}$ Popilian 1976, 182, nr. 370, pl. XXXVII/370.

102 Muşețeanu 2003, pl. 36/10.

103 Nicolić-Dordević 2000, 69, tipII/9.

104 Bolindeț et alli 2003, 427, fig. 32/92.

${ }^{105}$ Popilian 1976, 206, nr. 723, pl. LX/723.
}

(la Histria ${ }^{106}$ ) şi în Moesia Superior (la Singidunum ${ }^{107}$ ).

Capace (operculum ${ }^{108}$ ), frecvent întâlnite în mai toate aşezările romane, dar şi în necropole. Au fost recoltate şi catalogate trei exemplare (nr. cat. 1, 7, 16), toate fragmentare. Cele trei piese au fost descoperite în interiorul structurii constructive: nr. cat. 1 a fost descoperit în Cam. 1, nr. cat. 7 în Cam. 2, iar nr. cat. 16 în Cam. 5. Nici unul dintre aceste exemplare nu prezintă urme de ardere secundară. Acest tip îşi găseşte analogii în Dacia Inferior (la Drobeta $^{109}$ ) şi în Moesia Superior (la Singidunum ${ }^{110}$ ).

Opaițe (lucerna). Au fost recoltate 11 exemplare (nr. cat. 10, 35, 36, 37, 38, 39, 49, $58,66,74,82$ ), toate fragmentare. Toate cele 11 piese sunt de tipul Loeschcke $\mathrm{X}$, caracterizate prin disc rotund, plan sau uşor concav, cu un orificiu de alimentare, delimitat de bordură printr-un cordon, care se îndreaptă spre cioc îl înconjoară şi formează un canal, prevăzut cu un mic orificiu de aerisire. Bordura lată sau îngustă, în majoritatea cazurilor prevăzută cu doi sau trei butoni dispuşi aproximativ simetric, este decorată în câteva cazuri cu un rând de incizii radiale sau cu o rețea de incizii. Rezervor tronconic. Baza uşor concavă este delimitată de două sau trei cercuri concentrice incizate. $\mathrm{O}$ singură piesă a fost descoperită în interiorul structurii constructive (nr. cat. 10 în Cam. 3), restul de 10 exemplare fiind descoperite în exteriorul structurii constructive. Toate exemplarele sunt confecționate prin turnare în tipar bivalv. Piesele sunt utilizate atât în cadrul ceremonialului de înmormântare, având analogii la Roşia Montană, în necropola de incinerație de la Hop ${ }^{111}$, dar şi pentru iluminatul locuințelor, cu analogii la Roşia Montană (în

\footnotetext{
${ }^{106}$ Suceveanu 2000, 102, nr. 15, pl. 42/15.

${ }^{107}$ Nicolić-Dordević 2000, 176, tip IX/52.

${ }^{108}$ Hilgers 1969, 70.

${ }^{109}$ Popilian 1976, 218, nr. 901, pl. LXXII/901.

${ }^{110}$ Nicolić-Dordević 2000, 155, tip VIII/4.

${ }^{111}$ Moga et alii 2003, 236, fig. 22/10.
} 
structurile de habitat din zona Carpeni ${ }^{112}$ ), în Dacia Superior (la Ulpia ${ }^{113}$ ) şi în Pannonia ${ }^{114}$.

\section{B. Obiecte din fier}

Această categorie de obiecte este reprezentată prin cinci exemplare.

\section{Piroane}

Au fost recoltate trei piroane, două din interiorul structurii constructive (nr. cat. 8 din Cam. 2 şi nr. cat. 23 din V1) şi unul din exteriorul structurii cercetate (nr. cat. 40). Cele trei exemplare sunt nerestaurate şi într-o stare precară de conservare. Se înscriu în tipul piroanelor cu cap rotund şi corp cu secțiune pătrată.

\section{Cuie}

Categorie de obiecte mai puțin reprezentată printr-un singur exemplar (nr. cat. 41), descoperit în exteriorul complexului arheologic cercetat. Acesta este nerestaurat, aflat într-o stare precară de conservare.

\section{Material numismatic}

A fost descoperită o singură monedă, de argint (denar) datată după anul 141 p.Chr. (cat. nr. 22).

\section{$* * *$}

Deosebit de importantă ni se pare relația acestui atelier cu necropola romană de incinerație ulterioară. $\mathrm{O}$ serie de elemente descrise mai sus au demonstrat faptul că la un moment dat „atelierul” îşi încetează activitatea, din cauze greu de decelat (epuizarea zonei arondate exploatării, alte situații generate de posesiunea juridică a dreptului de exploatare?). De asemenea, întreaga situație arheologică constatată în cazul amenajării constructive sugerează că: 1) este vorba de o întreprindere de tip „artizanal”, foarte diferită de „fonderiile” oficiale; 2) din punctul de vedere al duratei

\footnotetext{
112 Rusu-Bolindeț et alii 2003, 416, fig. 20/36.

${ }^{113}$ Alicu 1994, pl. 15/596.

${ }^{114}$ Iványi 1935, pl. XLIX/7.
}

de funcționare este vorba de o structură cu elemente care indică o ocupare sezonieră.

Este foarte greu de realizat o legătură directă între utilizatorii „atelierului” şi identitatea defuncților din necropola de la Jig-Piciorag. Totuşi, pe baza anumitor elemente putem sugera o serie de elemente comune între preocupările legate de industria extractivă şi reflectarea acestora în anumite detalii legate mai mult de un comportament funerar specific şi mai puțin de elemente definitorii ale ritului.

Astfel, una dintre caracteristicile exploatării miniere specifice epocii romane la Roşia Montană este utilizarea profilaturii trapezoidale la galeriile subterane ${ }^{115}$. Aceeaşi profilatură trapezoidală se regăseşte în secțiunea gropilor mormintelor de incinerație din câteva dintre necropolele alburnense ${ }^{116}$, printre care şi în cazul a 6 morminte din necropole de la Jig-Piciorag ${ }^{117}$. De obicei este vorba de morminte bustum amenajate direct în roca moale, acolo unde solul vegetal este foarte subțire. Profilul trapezoidal al gropilor corespunzătoare mormintelor de incinerație nu este unul caracteristic necropolelor din Dacia romană, pentru care se utilizează de obicei formula de groapă albiată ${ }^{118}$. În stadiul actual al cercetării nu putem face alte considerații referitoare la această trăsătură comună a ambelor tipuri de excavație în afara celei legate de posibilitatea existenței unei

\footnotetext{
${ }^{115}$ Potrivit lui B. Cauuet această manieră de abordare a fronturilor de lucru în subteran este caracteristică sitului minier de la Roşia Montană. Aspectul trapezoidal este caracteristic galeriilor de cercetate, în general executate în roca moale. Pentru principalele rezultate ale cercetării arheologice în subteran, vezi Cauuet et alii 2003, 471-530; Cauuet, CCA 2002 (2003), 254; Cauuet, CCA 2003 (2004), 283-288.

${ }^{116}$ Morminte de incinerație bustum cu groapa de secțiune trapezoidală au fost identificate în următoarele necropole din perimetrul com. Roşia Montană: Hop-Găuri (Damian et alii, CCA 2002 (2003), 104-105, 62); Jig-Piciorag (Simion et alii, CCA 2003 (2004), 262-264, 160; Tăul Secuilor (Damian et alii, CCA 2004 (2005), 293-297.

${ }^{117}$ M 4, M 9, M 11, M 12, M 14, M 15.

${ }^{118}$ Despre problematica referitoare la analiza mormintelor de incinerație din provincia Dacia, precum şi pentru principalele repere bibliografice ale subiectului vezi Simion et alii 2004.
} 
unelte comune ambelor intervenții. Analiza traseologică a urmelor de pe pereții galeriilor $^{119}$ şi a celor, acolo unde sunt vizibile, de pe pereții gropilor mormintelor ${ }^{120}$ par sa indice o unealtă de tip daltă cu vârful lat a cărei modalitate de atac asupra rocii este una în plan oblic, de unde forma trapezoidală în cazul unei gropi.

Inventarul mormintelor din necropola de la Jig-Piciorag este unul tipic pentru necropolele de incineraţie din Dacia şi cele două Moesii. Totuşi prezența opaițelor în număr foarte mare, atât ca inventar funerar, cât şi ca depuneri secundare poate fi pusă în legătură cu preocupările economice ale comunității de care aparțineau defuncții ${ }^{121}$. Mai mult decât atât se constată, în cazul unuia dintre complexele funerare cercetate la Jig Piciorag (M8), amenajarea, în peretele orizontal al gropii de tiraj a unei nişe în care a fost depus un opait, realizată într-o manieră similară cu cele constatate pe pereții interiori ai galeriilor ${ }^{122}$.

Toate aceste elemente reuşesc, credem noi, să aducă o serie de clarificări atât în ceea ce priveşte cunoaşterea realităţilor arheologice caracteristice siturilor cu specific minier din Dacia (un domeniu relativ nou), precum şi în cazul anumitor nuanțe care țin de comportamentul funerar al diverselor comunități condiționate din punct de vedere economic.

\section{Catalogul selectiv al descoperirilor din structura constructivă ${ }^{123}$}

\footnotetext{
119 vezi Cauuet et alii 2003, p. 528, fig. 34; 530, fig. 40.

${ }^{120}$ Situație vizibilă în cazul M8 din necropola de la JigPiciorag.

${ }^{121}$ Despre semnificația depunerii opaițelor în morminte vezi RE, XIII, 1926, col. 1588, s.v. lucerna; Pâslaru, Bărbulescu 2003, 19-21.

${ }^{122}$ Cauuet et alii, loc. cit.

${ }^{123}$ Abrevierile utilizate în catalog sunt următoarele: $\mathrm{S}=$ secțiunea; $\square$ = caroul; a = adâncimea; cca. = circa; $\mathrm{db}=$ diametrul bază; dbuton = diametrul buton; $\mathrm{dg}=$ diametrul gurii; $\mathrm{D}$ int $=$ diametrul exterior; $\mathrm{D}$ ext $=$ diametrul exterior; hp = înălțimea păstrată; $\mathrm{L}=$ lungime; $\mathrm{Lp}=$ lungimea păstrată; $l$ = lățime; $l p=$ lățimea păstrată; gr = grosime; $\mathrm{cm}$ = centimetru; $\mathrm{m}=$ metru; $\max$. = maximă.
}

Cam. 1:

1. Capac (fragmentar, se păstrează un fragment din margine şi şapte fragmente din corp); S 006; $\square$ 1/a-b; a = 0,40 m; dg = $18 \mathrm{~cm}$; hp $=1,7 \mathrm{~cm}$. Pastă grosieră, de culoare portocalie (5YR 6/8), cu multe incluziuni de cuarț alb şi cenuşiu, calcit, oxizi de fier, pirită şi rare paiete fine de mică. Ardere primară incompletă. Uşor afectat de aciditatea solului. Buza îngroşată, rotunjită, delimitată. Analogii: Heukemes 1964, 73, nr. 129, pl. 18/129 (sec. II); Popilian 1976, 218, nr. 901, pl. LXXII/901, tip 1 (sec. II-III); Nicolić-Dordević 2000, 155, tip VIII/4 (sec. IIIV). Datare: sec. II. Pl. VII/1.

2. Masă de măcinat (fragmentară); S 006; $\square$ 2-3/a; L = 0,31 m (max.); l = 0,15 m (max.); gr $=0,10 \mathrm{~m}$ (max.). Roca de bază: vulcano-clastit (andezit ?). Partea stabilă a piesei este şlefuită cu urme de frecare. Piesa prezintă urme de tratament termic (sau chimic ?), fiind pe alocuri înroşită (nuanţa de plumb). Pl. VII/2.

Cam. 2:

3. Oală (fragmentară, se păstrează un fragment din buză); S 004; $\square$ 3/e; a = 0,30 m; dg $=12,5 \mathrm{~cm} ; \mathrm{hp}=3 \mathrm{~cm}$. Pastă grosieră, de culoare portocalie (5YR 6/8), cu multe incluziuni de cuarț alb şi cenuşiu, calcit, oxizi de fier, pirită şi rare paiete fine de mică în compoziție. Ardere primară incompletă. Slabe urme de ardere secundară. Buza îngroşată, rotunjită, uşor înclinată spre exterior. Analogii: Popilian 1976, p. 182, nr. 369, pl. XXXVI/369, tip 11 (sfârşitul sec. II); Brukner 1981, 105, nr. 55, pl. 113/52 (sec. I-II); NicolićDordević 2000, 70, tip II/10 (sec. II-IV). Datare: sfârşitul sec. II-începutul sec. III. Pl. VII/3.

4. Oală (fragmentară, se păstrează trei fragmente din corp cu dimensiuni cuprinse între 4,5-6,5 cm); S 004; $\square$ 1/e; a = 0,45 m. Pastă grosieră, de culoare portocalie (5YR 6/8), cu multe incluziuni de cuarţ alb şi cenuşiu, calcit, oxizi de fier, pirită şi rare paiete fine de mică în compoziţie. Ardere primară uniformă. Uşor afectată de aciditatea solului.

5. Oală (fragmentară, se păstrează două fragmente din corp cu dimensiuni de 5,6 × 6,2 cm); S 004; $\square$ 2/e; a = 0,32 m. Pastă grosieră, de culoare portocalie (5YR 6/8), cu multe incluziuni de cuarţ alb şi cenuşiu, calcit, oxizi de fier, pirită şi rare paiete fine de mică în compoziţie. Ardere 
primară incompletă. Slabe urme de ardere secundară.

6. Oală (fragmentară, se păstrează cinci fragmente din corp cu dimensiuni cuprinse între 3-4,5 cm); S 004; $\square$ 1/e; a = 0,60 m. Pastă grosieră, de culoare portocalie (5YR 6/8), cu multe incluziuni de cuarț alb şi cenuşiu, calcit, oxizi de fier, pirită şi rare paiete fine de mică în compoziţie. Ardere primară incompletă. Slabe urme de ardere secundară la exterior.

7. Capac (fragmentar, se păstrează trei fragmente din partea inferioară); S 010; $\square$ 2/a; a = $0,40 \mathrm{~m} ; \mathrm{dg}=23 \mathrm{~cm} ; \mathrm{hp}=4,5 \mathrm{~cm}$. Pastă grosieră, de culoare portocalie (5YR 6/8), cu multe incluziuni de cuarț alb şi cenuşiu, calcit, oxizi de fier, pirită şi rare paiete fine de mică în compoziție. Ardere primară incompletă. Analogii: Popilian 1976, p. 219, nr. 924, pl. LXXIII/924, tip 3 (sec. II); Hüssen 2000, pl. 76/9 (sec. II); Nicolić-Dordević 2000, 155, tip VIII/4 (sec. IIIV). Datare: sec. II. Pl. VII/7.

8. Piron (fragmentar). S 004; $\square$ 1/c; $a=$ $0,45 \mathrm{~m} . \mathrm{Lp}=11,7 \mathrm{~cm}$. Fier oxidat, puternic corodat. Nerestaurat. Cap rotund, parțial păstrat. Corp uşor îndoit, puternic afectat de coroziune. Vârf rupt. Pl. VII/8.

\section{Cam. 3:}

9. Oală (fragmentară, se păstrează un fragment din bază şi altul din corp, cu dimensiuni cuprinse între 2,6-3,5 cm); S 015; $\square$ 2/e; a = 0,40 m. Pastă grosieră, de culoare portocalie (5YR 6/8), cu multe incluziuni de cuarț alb şi cenuşiu, calcit, oxizi de fier, pirită şi rare paiete fine de mică în compoziție. Ardere primară incompletă. Baza dreaptă.

10. Opait Loeschcke $X$ (fragmentar, se păstrează două fragmente din bază şi rezervor, cu dimensiuni cuprinse între 3-4 cm); S 015; $\square$ 12/c; a $=0,37-0,40 \mathrm{~m}$. Pastă fină, de culoare portocalie (5YR 6/8), cu incluziuni moderate de oxizi de fier, mică şi cuarț alb în compoziție. Firnis roşu (2.5YR 4/8). Ardere primară uniformă.

\section{Cam. 4:}

11. Oală (fragmentară, se păstrează un fragment din bază şi altul din corp); S 009; $\square 1-$ 4/c; lângă Z7; a = 0,48 m; db = 7,1 cm; hp = 1,7 cm. Pastă semifină, de culoare portocalie (5YR
6/6), cu incluziuni de cuarț alb, oxizi de fier, calcit şi mică în compoziție. Ardere primară incompletă. Baza dreaptă. Analogii: Popilian 1976, 182, nr. 369, pl. XXXVI/369, tip 11 (sfârşitul sec. II); Brukner 1981, 105, nr. 55, pl. 113/52 (sec. I-II); Nicolić-Dordević 2000, 70, tip II/10 (sec. II-IV). Datare: sfârşitul sec. II-începutul sec. III. Pl. VIII/11.

12. Capac (fragmentar, se păstrează un fragment din buton cu corp); S 006; $\square$ 3/e; a = $0,50 \mathrm{~m}$; dbuton $=6,9 \mathrm{~cm} ; \mathrm{hp}=5,4 \mathrm{~cm}$. Pastă grosieră, de culoare portocalie (5YR 6/6), cu multe incluziuni de cuarț alb, oxizi de fier şi calcit în compoziție. Ardere primară uniformă. Urme de ardere secundară. Buton rotund, profilat. Pereți oblici. Analogii: Popilian 1976, 218, nr. 900, pl. LXXII/900, tip 1 (sec. II); Nicolić-Dordević 2000, 158, tipVIII/16 (sec. II-III); Damian et alii 2003, 95, nr. 34, fig. 27/34 (sec. II-III). Datare: sec. II. Pl. VIII/12.

13. Masă de măcinat (fragmentară); $S$ 009; $\square$ 3/a-b; Dimensiuni: 0,68x0,31 m; h = 0,16 $\mathrm{m}$. L ,prag” = 0,16 m. Concavitate $=0,05-0,10 \mathrm{~m}$. Roca de bază pare a fi vulcanică. Urme de tratament chimic (?) sau termic (?). Partea superioară (zona de impact-de frecare) foarte şlefuită şi cu urme de frecare foarte vizibile. Concavitatea este foarte pronunțată, despărțită de corpul piesei de un „prag” (stop). Cea mai mare parte a piesei este reprezentată de concavitate. „Pragul” are o formă relativ rectangulară (cca 0,22 X 0,19 m), foarte plană, ca suprafață. Pl. VIII/13.

\section{Cam. 5:}

14. Oală (fragmentară, se păstrează fragmente din buză şi corp); S 004; $\square$ 3/d; a = $0,37 \mathrm{~m}$; dg = $19 \mathrm{~cm}$; hp = 3,7 cm. Pastă grosieră, de culoare portocalie (5YR 6/8), cu multe incluziuni de cuarț alb şi cenuşiu, calcit, oxizi de fier, pirită şi rare paiete fine de mică în compoziție. Ardere primară uniformă. Slabe urme de ardere secundară. Buza uşor îngroşată, rotunjită, înălțată vertical, cu şănțuire internă pentru capac. Analogii: Popilian 1976, 180, nr. 333, pl. XXXIV/333, tip 3 (sec. II-III); Brukner 1981, 105, nr. 59, pl. 114/59 (sec. I-III); NicolićDordević 2000, 84, tip II/46 (sec. II); RusuBolindeț et alii 2003, 327, nr. 52, fig. 23/52 (sec. 
II); Muşețeanu 2003, pl. 38/46 (sec. II). Datare: sfârşitul sec. II. Pl. VIII/14.

15. Oală (fragmentară, se păstrează două fragmente din buză şi corp); S 004; $\square$ 2/d; a = $0,45 \mathrm{~m} ; \mathrm{dg}=13,5 \mathrm{~cm} ; \mathrm{hp}=4,9 \mathrm{~cm}$. Pastă grosieră, de culoare portocalie (5YR 6/6), cu multe incluziuni de cuarț alb, oxizi de fier şi calcit în compoziție. Ardere primară uniformă. Urme de ardere secundară. Buza îngroşată, rotunjită, înălțată vertical, cu şănțuire internă pentru capac. Analogii: Popilian 1976, 180, nr. 333, pl. XXXIV/333, tip 3 (sec. II-III); Brukner 1981, 105, nr. 59, pl. 114/59 (sec. I-III); NicolićDordević 2000, 84, tip II/46 (sec. II); Bolindeț et alii 2003, 327, nr. 52, fig. 23/52 (sec. II); Muşețeanu 2003, pl. 38/46 (sec. II). Datare: sfârşitul sec. II. Pl. VIII/15.

16. Capac (fragmentar, se păstrează două fragmente din margine); S 002; $\square 2$; a = 0,40 m; $\mathrm{dg}=28 \mathrm{~cm} ; \mathrm{hp}=2,8 \mathrm{~cm}$. Pastă grosieră, de culoare brun deschis (7.5YR 6/4), cu incluziuni de cuarţ alb şi cenuşiu, calcit şi oxizi de fier în compoziție. Ardere primară incompletă. Uşor afectat de aciditatea solului. Marginea uşor teşită şi îngroşată. Analogii: Popilian 1976, 218, nr. 913, pl. LXXII/913, tip 3 (sec. II); Hüssen 2000, pl. 76/9 (sec. II); Nicolić-Dordević 2000, 155, tip VIII/4 (sec. II-IV). Datare: sec. II. Pl. IX/16.

17. Mojar (fragmentar, se păstrează jumătate din piesă, fiind ,secționată” vertical). S 004, $\square$ 2/c-d; L (inferior) $=0,49 / 0,50 \mathrm{~m} ; \mathrm{L}$ (exterior) $=0,57 \mathrm{~m}$; D int (la gură) $=0,09 \mathrm{~m} ; \mathrm{D}$ ext (la fund) $=0,23 \mathrm{~m}$; gr fund $=0,10 \mathrm{~m}$. Grosimea pereților este variabilă: gr gură $=0,08$ m. gr spre bază $=0,10$ m. Faţa interioară are un diametru de cca. 0,09 m (tubular cu partea inferioară rotunjită). Roca de bază este andezitul (vulcano-clastitul). Este vizibilă aceeaşi preocupare pe exterior pentru relativa fasonare $\mathrm{cu}$ efect de laturi. Totuşi fețele sunt foarte grosier prelucrate. Pe interior sunt vizibile urmele de frecare. Pl. IX/17.

\section{1:}

18. Mojar (fragmentar); S 004, $\square$ 3-4/c; L $=0,23 \mathrm{~m}(\max ) ; \mathrm{l}=0,12 \mathrm{~m}(\max ) ; \mathrm{gr}=0,05 \mathrm{~m}$ (max). Piesă de andezit; una din fețe şlefuită (concavă). Partea netedă are urme de la frecare (şlefuire). Pl. IX/18.
19. Mojar (fragmentar, se păstrează un fragment partea inferioară). S 004, $\square$ 4/c; D int = cca $0,12 \mathrm{~m} ; \mathrm{D}$ ext $=$ cca. $0,22 \mathrm{~m}$ (toate dimensiunile se referă la partea strict prezervată). Grosimea peretelui nu este constantă (prealabil realizatorul a trebuit să țină cont de caracteristicile unei bucăți de piatră deja existente). gr (max) = $0,08 \mathrm{~m}$; gr $(\min )=0,02-0,03 \mathrm{~m}$. Piesa se păstrează pe înălțime de cca 0,20 m. D părții dorsale (talpa-zona de sprijin) = 0,24 m; gr (fund) $=0,13 \mathrm{~m}$. Roca de bază este vulcano-clastit. Pe fund este vizibil un precipitat solidificat, de culoare brun-ruginie. În secțiune orizontală pare să aibă o formă trapezoidală (cu trei laturi oarecum mai fațetate). Fața interioară foarte şlefuită, poartă urme de frecare. Fundul pare să aibă urme de prelucrare (realizarea unei suprafețe plane pentru sprijin). Pl. IX/19.

\section{2:}

20. Urcior (fragmentar, se păstrează patru fragmente din partea superioară a corpului cu dimensiuni cuprinse între 3,5-5,2 cm). S 009; $\square$ $1 / a ; a=0,75-0,80$ m. Pastă grosieră, de culoare portocalie (5YR 6/8), cu multe incluziuni de cuarț alb şi cenuşiu, calcit, oxizi de fier, pirită şi rare paiete fine de mică în compoziție. Ardere primară uniformă. Uşor afectat de aciditatea solului.

21. Oală (fragmentară, se păstrează un fragment din corp cu dimensiuni de 7,7 ×6 cm); S 009; $\square 1 / \mathrm{a} ; \mathrm{a}=0,74 \mathrm{~m}$. Pastă grosieră, de culoare portocalie (5YR 6/8), cu multe incluziuni de cuarț alb şi cenuşiu, calcit, oxizi de fier, pirită şi rare paiete fine de mică în compoziţie. Ardere primară incompletă. Ardere secundară.

22. Monedă. S006; $\square$ 1/c; $a=0,55 \mathrm{~m}$; Antoninus Pius: Diva Faustina; denar; AR $\downarrow 2,28$ g; 17,2 × 18,1 mm. Av. DIVA-FAVSTINA; bust spre dreapta. Rv. AETE-R-NITAS; Aeternitas spre stânga, ținând phoenix în mâna dreaptă şi un fald al veşmântului cu mâna stângă. Analogii: BMC, IV, 54, nr. 354, Roma, după anul 141, dar cu altă organizare a legendei de revers.

\section{1:}

23. Piron (fragmentar). S 002; $\square$; $\mathrm{a}=$ $0,25 \mathrm{~m} . \mathrm{Lp}=5 \mathrm{~cm}$. Fier oxidat, puternic corodat. Nerestaurat. Cap rotund, puternic afectat de coroziune. Corp parțial păstrat, cu secțiune pătrată: 0,5 cm. Vârf rupt. Pl. X/23 


\section{Catalogul descoperirilor din afara structurii constructive}

24. Oală (fragmentară, se păstrează un fragment din buză cu corp); S 001; $\square 1-2$; a = $0,1-0,25 \mathrm{~m} ; \mathrm{dg}=12 \mathrm{~cm} ; \mathrm{hp}=2,8 \mathrm{~cm}$. Pastă grosieră, de culoare brun deschis (7.5YR 6/4), cu incluziuni de cuarț alb şi cenuşiu, calcit şi oxizi de fier în compoziţie. Ardere primară incompletă. Buza îngroşată, rotunjită, înălțată vertical. Analogii: Popilian 1976, 180, nr. 333, pl. XXXIV/333, tip 3 (sec. II-III); Brukner 1981, 105, nr. 59, pl. 114/59 (sec. I-III); NicolićDordević 2000, 84, tip II/46 (sec. II); RusuBolindeț et alii 2003, 327, nr. 52, fig. 23/52 (sec. II); Muşețeanu 2003, pl. 38/46 (sec. II). Datare: sfârşitul sec. II. Pl. X/24.

25. Oală (fragmentară, se păstrează un fragment din buză cu corp); S 001; $\square$ 1-2; a = $0,1-0,25 \mathrm{~m} ; \mathrm{dg}=11 \mathrm{~cm} ; \mathrm{hp}=1,8 \mathrm{~cm}$. Pastă grosieră, de culoare portocalie (5YR 6/8), cu multe incluziuni de cuarț alb şi cenuşiu, calcit, oxizi de fier, pirită şi rare paiete fine de mică în compoziție. Ardere primară uniformă. Puternic arsă secundar. Buza îngroşată, triunghiulară în secțiune, înclinată spre exterior. Analogii: Brukner 1981, 105, nr. 59, pl. 114/59 (sec. I-III); Nicolić-Dordević 2000, 81, tip II/39 (sec. II-IV). Datare: începutul sec. III. Pl. X/25.

26. Oală (fragmentară, se păstrează un fragment din buză şi altul din corp); S 001; $\square$ 1; a $=0,50-0,60 \mathrm{~m} ; \mathrm{dg}=10,2 \mathrm{~cm} ; \mathrm{hp}=2,6 \mathrm{~cm}$. Pastă grosieră, de culoare portocalie (5YR 6/8), cu multe incluziuni de cuarț alb şi cenuşiu, calcit, oxizi de fier, pirită şi rare paiete fine de mică în compoziție. Ardere primară uniformă. Buza rotunjită, îngroşată înclinată spre exterior. Analogii: Popilian 1976, 182, nr. 369, pl. XXXVI/369, tip 11 (sfârşitul sec. II); Brukner 1981, 105, nr. 55, pl. 113/52 (sec. I-II); NicolićDordević 2000, 70, tip II/10 (sec. II-IV). Datare: sfârşitul sec. II-începutul sec. III. Pl. X/26.

27. Oală (fragmentară, se păstrează un fragment din bază cu corp); S 001; $\square$ 2; a = 0,50 $\mathrm{m} ; \mathrm{db}=14 \mathrm{~cm} ; \mathrm{hp}=2 \mathrm{~cm}$. Pastă semifină, de culoare portocalie (5YR 6/6), cu incluziuni de cuarț alb şi cenuşiu, oxizi de fier, pirită şi rare paiete fine de mică în compoziție. Ardere primară incompletă. Ardere secundară la exterior. Puternic afectată de aciditatea solului. Baza dreaptă. Analogii: Popilian 1976, 180, nr. 338, pl. XXXIV/338, tip 3 (sec. II-III); Brukner 1981, 105, nr. 59, pl. 114/59 (sec. I-III); NicolićDordević 2000, 84, tip II/46 (sec. II); RusuBolindeț et alii 2003, 327, nr. 52, fig. 23/52 (sec. II); Muşețeanu 2003, pl. 38/46 (sec. II). Datare: sfârşitul sec. II. Pl. X/27.

28. Oală (fragmentară, se păstrează un fragment din bază cu corp); S 001; $\square 3$; a $=0,37$ $\mathrm{m} ; \mathrm{db}=4 \mathrm{~cm} ; \mathrm{hp}=2 \mathrm{~cm}$. Pastă grosieră, de culoare portocalie (5YR 6/8), cu multe incluziuni de cuarţ alb şi cenuşiu, calcit, oxizi de fier, pirită şi rare paiete fine de mică în compoziție. Ardere primară uniformă. Baza dreaptă. Analogii: Popilian 1976, 182, nr. 369, pl. XXXVI/369, tip 11 (sfârşitul sec. II); Brukner 1981, 105, nr. 55, pl. 113/52 (sec. I-II); Nicolić-Dordević 2000, 70, tip II/10 (sec. II-IV). Datare: sfârşitul sec. IIînceputul sec. III. Pl. X/28.

29. Oală (fragmentară, se păstrează două fragmente din corp cu dimensiuni cuprinse între 2,7-6,6 cm); S 001; $\square$ 2; a = 0,70-0,80 m. Pastă grosieră, de culoare portocalie (5YR 6/8), cu multe incluziuni de cuarţ alb şi cenuşiu, calcit, oxizi de fier, pirită şi rare paiete fine de mică în compoziție. Ardere primară incompletă. Ardere secundară.

30. Oală (fragmentară, se păstrează un fragment din corp cu dimensiuni de 3,5 × 2,4 cm); S 001; $\square 2$; a $=0,40$ m. Pastă grosieră, de culoare portocalie (5YR 6/8), cu multe incluziuni de cuarț alb şi cenuşiu, calcit, oxizi de fier, pirită şi rare paiete fine de mică în compoziție. Ardere primară uniformă.

31. Oală (fragmentară, se păstrează un fragment din corp cu dimensiuni de $3 \times 2,4 \mathrm{~cm}$ ); S 001; $\square 3$; a = 0,47 m. Pastă grosieră, de culoare portocalie (5YR 6/8), cu multe incluziuni de cuarț alb şi cenuşiu, calcit, oxizi de fier, pirită şi rare paiete fine de mică în compoziție. Ardere primară incompletă. Ardere secundară pe interior.

32. Oală (fragmentară, se păstrează un fragment din corp cu dimensiuni de $3 \times 1,7 \mathrm{~cm}$ ); S 001; $\square 1 ; \mathrm{a}=0,20$ m. Pastă grosieră, de culoare portocalie (5YR 6/8), cu multe incluziuni de cuarț alb şi cenuşiu, calcit, oxizi de fier, pirită şi rare paiete fine de mică în compoziție. Ardere primară incompletă. 
33. Oală (fragmentară, se păstrează un fragment din corp cu dimensiuni de 2,7 × 1,3 cm); S 001; $\square 3$; a = 0,40 m. Pastă grosieră, de culoare portocalie (5YR 6/8), cu multe incluziuni de cuarț alb şi cenuşiu, calcit, oxizi de fier, pirită şi rare paiete fine de mică în compoziție. Ardere primară uniformă. Uşor afectată de aciditatea solului.

34. Oală (fragmentară, se păstrează un fragment din toartă cu dimensiuni de $3 \times 2,4 \mathrm{~cm}$ ); S 001; $\square$ 3; a = 0,20 m. Pastă grosieră, de culoare portocalie (5YR 6/8), cu multe incluziuni de cuarț alb şi cenuşiu, calcit, oxizi de fier, pirită şi rare paiete fine de mică în compoziție. Ardere primară uniformă. Toartă lată, canelată. Pl. X/34.

35. Opait Loeschcke $X$ (fragmentar, se păstrează o parte din capac: disc, bordură, canal); S 001; $\square 1 ; \mathrm{a}=0,43 \mathrm{~m} ; \mathrm{Lp}=6,8 \mathrm{~cm} ; \mathrm{l}=5,5 \mathrm{~cm}$; hp $=0,8 \mathrm{~cm}$. Pastă fină, de culoare portocalie (5YR 6/8), cu oxizi de fier şi incluziuni de cuarț alb în compoziţie. Firnis roşu (2.5YR 4/8). Ardere primară uniformă. Disc neted, rotund, cu un orificiu de alimentare în centru, delimitat de bordură printr-un cordon, care se îndreaptă spre cioc şi formează un canal, prevăzut cu un mic orificiu de aerisire. Bordura prevăzută cu trei butoni, dispuşi aproximativ simetric. Analogii: Iványi 1935, pl. XLIX/7 (sec. II); Kuzmanov 1992, 105, fig. 247 a (sec. II); Alicu 1994, pl. 15/596 (sec. II); Moga et alii 2003, 236, fig. 22/10 (sec. II). Datare: sec. II. Pl. X/35.

36. Opait Loeschcke $\mathbf{X}$ (fragmentar, se păstrează fragmente din disc şi bordură); S 001; $\square$ 2; a $=0,70 \mathrm{~m} ; \mathrm{Lp}=7 \mathrm{~cm}$; l estimativă $=5,3 \mathrm{~cm}$. Pastă fină, de culoare portocalie (7.5YR 6/6), cu o cantitate moderată de incluziuni de calcit şi oxizi de fier, rare incluziuni de cuarț cenuşiu în compoziţie. Firnis roşu (10R 4/6). Ardere primară uniformă. Uşor afectat de aciditatea solului. Disc neted, delimitat de bordură printr-un cordon, care se îndreaptă spre cioc şi formează un canal. Bordura, prevăzută cu trei butoni, dispuşi aproximativ simetric este decorată pe întreaga suprafață cu o rețea de incizii. Analogii: Alicu 1994, pl. 8/441 (sec. II); Moga et alii 2003, 243, fig. 29/8 (sec. II). Datare: sec. II. Pl. X/36.

37. Opait Loeschcke $\mathbf{X}$ (fragmentar, se păstrează o parte din capac: disc şi bordură); S 001, $\square 1, a=0,50 \mathrm{~m} ; \mathrm{Lp}=4,9 \mathrm{~cm} ; \mathrm{lp}=3 \mathrm{~cm}$. Pastă fină, de culoare portocalie (5YR 6/8), cu oxizi de fier şi incluziuni de cuarț alb în compoziție. Firnis roşu (2.5YR 4/8). Ardere primară incompletă. Disc neted, cu un orificiu de alimentare, delimitat de bordură printr-un cordon proeminent. Bordura păstrează un buton. Analogii: Iványi 1935, pl. XLIX/7 (sec. II); Kuzmanov 1992, 105, fig. 247 a (sec. II); Alicu 1994, pl. 15/596 (sec. II); Rusu-Bolindeț et alii 2003, 416, fig. 20/36 (sec. II). Datare: sec. II. Pl. $\mathrm{X} / 37$.

38. Opaiț Loeschcke $\mathbf{X}$ (fragmentar, se păstrează un fragment din bază cu rezervor); S 001; $\square$ 3-4; a = 0,20 m; Lp = 3,2 cm; lp = 2 cm. Pastă fină, de culoare portocalie (5YR 6/8), cu oxizi de fier şi incluziuni de cuarț alb în compoziție. Ardere primară uniformă. Baza uşor concavă este delimitată de două cercuri concentrice incizate. $\mathrm{Pl}$. X/38.

39. Opaiț Loeschcke $X$, fragmentar (se păstrează un fragment din bază şi altul din cioc cu dimensiuni de 3,5 × 1,7 cm); S 001; $\square 3$; a = 0,37 m. Pastă fină, de culoare portocalie (5YR 6/8), cu oxizi de fier şi incluziuni de cuarț alb în compoziție. Ardere primară incompletă. Urme de materie organică pe interior. Cioc alungit, cu un arzător. Baza uşor concavă este delimitată de două cercuri concentrice incizate. Pl. X/39

40. Piron (fragmentar). S 001; $\square 2$; $\mathrm{a}=$ 0,70-0,89 m. Lp $=5 \mathrm{~cm}$. Fier oxidat, puternic corodat. Nerestaurat. Cap rotund, puternic afectat de coroziune. Corp parțial păstrat, îndoit, afectat de coroziune. Vârf rupt. Pl. X/40.

41. Cui (fragmentar). S 001; $\square 2$; $\mathrm{a}=$ 0,70-0,80 m. Lp =3,8 cm. Fier oxidat, puternic corodat. Nerestaurat. Cap rupt. Corp parțial păstrat, puternic afectat de coroziune. Vârf tocit. Pl. X/41.

42. Oală (fragmentară, reîntregibilă ca formă se păstrează fragmente din buză, corp şi bază); S 002; $\square$ 4; a = 0,27 m; dg = 14,2 cm; db = $8 \mathrm{~cm} ;$ h estimativ $=15 \mathrm{~cm}$. Pastă grosieră, de culoare portocalie (5YR 6/8), cu multe incluziuni de cuarț alb şi cenuşiu, calcit, oxizi de fier, pirită şi rare paiete fine de mică în compoziție. Ardere primară uniformă. Buza înălţată vertical, uşor rotunjită cu şănțuire internă pentru capac. Corp globular, cu diametrul maxim în partea superioară. Baza dreaptă. Analogii: Popilian 1976, 180, nr. 333, pl. XXXIV/333, tip 3 (sec. II-III.); Brukner 1981, 105, nr. 59, pl. 114/59 (sec. I-III); Nicolić-Dordević 2000, 84, tip II/46 (sec. II); 
Rusu-Bolindeț et alii 2003, 327, nr. 52, fig. 23/52 (sec. II); Muşețeanu 2003, pl. 38/46 (sec. II). Datare: sfârşitul sec. II. Pl. X/42.

43. Oală (fragmentară, se păstrează un fragment din partea superioară); S 002; $\square$ 4; a = 0,27 m. Pastă grosieră, de culoare portocalie (5YR 6/8), cu multe incluziuni de cuarț alb şi cenuşiu, calcit, oxizi de fier, pirită şi rare paiete fine de mică în compoziție. Ardere primară uniformă. Buza înălțată vertical, rotunjită, cu şănțuire internă pentru capac. Urmă de toartă sub buză. Analogii: Popilian 1976, 182, nr. 370, pl. XXXVII/370 (sec. II); Zotović-Jordović 1990, pl. CXXXV/13 (sec. II); Nicolić-Dordević 2000, 69, tip II/9 (sec. II-V); Muşețeanu 2003, pl. 36/10 (sec. II). Datare: sec. II. Pl. X/43.

44. Oală (fragmentară, se păstrează un fragment din buză); S 002; $\square$ 4; a = 0,20 m; dg = $14 \mathrm{~cm} ; \mathrm{hp}=3 \mathrm{~cm}$. Pastă grosieră, de culoare portocalie (5YR 6/8), cu multe incluziuni de cuart alb şi cenuşiu, calcit, oxizi de fier, pirită şi rare paiete fine de mică în compoziție. Ardere primară uniformă. Urme de ardere secundară. Buza înălțată vertical, rotunjită, cu şănţuire internă pentru capac. Corp bombat (?). Analogii: Popilian 1976, 180, nr. 333, pl. XXXIV/333, tip 3 (sec. IIIII); Brukner 1981, 105, nr. 59, pl. 114/59 (sec. IIII); Nicolić-Dordević 2000, 84, tip II/46 (sec. II); Rusu-Bolindeț et alii 2003, 327, nr. 52, fig. 23/52 (sec. II); Muşețeanu 2003, pl. 38/46 (sec. II). Datare: sfârşitul sec. II. Pl. XI/44.

45. Oală (fragmentară, se păstrează un fragment din buză). S 002; $\square 5$, a $=0,20 \mathrm{~m}$; dg = $13 \mathrm{~cm} ; \mathrm{hp}=2,1 \mathrm{~cm}$. Pastă grosieră, de culoare portocalie (5YR 6/8), cu multe incluziuni de cuart alb şi cenuşiu, calcit, oxizi de fier, pirită şi rare paiete fine de mică în compoziție. Ardere primară incompletă. Buza rotunjită, îngroşată, triunghiulară în secțiune, uşor înclinată spre exterior. Analogii: Brukner 1981, 105, nr. 59, pl. 114/59 (sec. I-III); Nicolić-Dordević 2000, 81, tip II/39 (sec. II-IV). Datare: începutul sec. III. Pl. XI/45.

46. Oală (fragmentară, se păstrează trei fragmente din bază şi două din toartă cu corp); din martorul stratigrafic dintre S 002 şi S 005; a = $0,60 \mathrm{~m} ; \mathrm{db}=10 \mathrm{~cm} ; \mathrm{hp}=3 \mathrm{~cm}$. Pastă grosieră, de culoare portocalie (5YR 6/8), cu multe incluziuni de cuarț alb şi cenuşiu, calcit, oxizi de fier, pirită şi rare paiete fine de mică în compoziție. Ardere primară uniformă. Toarta lată, canelată. Baza dreaptă. Analogii: Popilian 1976, 182, nr. 370, pl. XXXVII/370 (sec. II); Zotović-Jordović 1990, pl. CXXXV/13 (sec. II); Nicolić-Dordević 2000, 69, tip II/9 (sec. II-V). Datare: sec. II. Pl. XI/46.

47. Oală (fragmentară, se păstrează un fragment din corp cu dimensiuni de 5,5 $\times 5 \mathrm{~cm}$ ). $S$ 002 ; $\square$; a $=0,40 \mathrm{~m}$. Pastă grosieră, de culoare portocalie (5YR 6/8), cu multe incluziuni de cuarț alb şi cenuşiu, calcit, oxizi de fier, pirită şi rare paiete fine de mică în compoziție. Ardere primară uniformă.

48. Cupă (fragmentară, se păstrează un fragment din bază); S 002; $\square 5$; a $=0,32 \mathrm{~m}$; db = $3,2 \mathrm{~cm} ; \mathrm{hp}=2,1 \mathrm{~cm}$. Pastă fină, de culoare portocalie (5YR 6/8), cu oxizi de fier şi incluziuni de cuarț alb în compoziție Ardere primară uniformă. Puternic afectată de aciditatea solului. Baza inelară cu un mic umbo în centru. Analogii: Popilian 1976, 206, nr. 728, pl. LX/728, tip 4 (sec. II); Nicolić-Dordević 2000, 161, tip IX/3 (sec. II); Rusu-Bolindeț el alii 2003, 399, nr. 92, fig. 32/92 (sec. II). Datare: sec. II. Pl. XI/48.

49. Opait Loeschcke $X$ (fragmentar, se păstrează două fragmente din rezervor şi bază); $S$ 002; $\square-1 ; \mathrm{a}=0,40 \mathrm{~m}$. Pastă fină, de culoare portocalie (7.5YR 6/6), cu o cantitate moderată de incluziuni de calcit şi oxizi de fier, rare incluziuni de cuarț cenuşiu în compoziție. Ardere primară uniformă. Puternic afectat de aciditatea solului. Rezervor tronconic. Baza dreaptă. Analogii: Iványi 1935, pl. XLIX/7 (sec. II); Kuzmanov 1992, 105, fig. 247 a (sec. II); Alicu 1994, pl. 15/596 (sec. II); Moga et alii 2003, 236, fig. 22/10 (sec. II). Datare: sec. II. Pl. XI/49.

50. Dolium (fragmentar, se păstrează nouă fragmente din buză şi corp); S 003; $\square 5$; a = 0,38 $\mathrm{m} ; \mathrm{dg}=20 \mathrm{~cm} ; \mathrm{hp}=6,4 \mathrm{~cm}$. Pastă semifină, de culoare portocalie (5YR 6/6), cu incluziuni de cuarț alb şi cenuşiu, oxizi de fier, pirită şi rare paiete fine de mică în compoziție. Ardere primară incompletă. Uşor afectat de aciditatea solului. Buza lată, rotunjită şi îngroşată, înclinată spre exterior până la orizontală. Corp bombat (?). Analogii: Brukner 1981, 96, nr. 112, pl. 89/112 (sec. II-III); Damian et alii 2003, 118, fig. 26/27 (a doua jumătate a sec. II p.Chr.). Datare: sec. al II. Pl. XI/50.

51. Oală (fragmentară, se păstrează un fragment din bază); S 003; $\square$ 2/c; a $=0,40 \mathrm{~m}$; db $=16 \mathrm{~cm} ; \mathrm{hp}=1,8 \mathrm{~cm}$. Pastă semifină, de culoare 
portocalie (5YR 6/6), cu incluziuni de cuarț alb şi cenuşiu, oxizi de fier, pirită şi rare paiete fine de mică în compoziție. Ardere primară uniformă. Uşor afectată de aciditatea solului. Baza dreaptă. Analogii: Popilian 1976, 180, nr. 333, pl. XXXIV/333, tip 3 (sec. II-III.); Brukner 1981, 105, nr. 59, pl. 114/59 (sec. I-III); NicolićDordević 2000, 84, tip II/46 (sec. II); RusuBolindeț et alii 2003, 327, nr. 52, fig. 23/52 (sec. II); Muşețeanu 2003, pl. 38/46 (sec. II). Datare: sfârşitul sec. II. Pl. XI/51.

52. Oală (fragmentară, se păstrează un fragment din buză cu corp); S 003; $\square$ 1/a-b; a = $0,40 \mathrm{~m} ; \mathrm{dg}=14,5 \mathrm{~cm} ; \mathrm{hp}=3,2 \mathrm{~cm}$. Pastă grosieră, de culoare portocalie (5YR 6/8), cu multe incluziuni de cuarț alb şi cenuşiu, calcit, oxizi de fier, pirită şi rare paiete fine de mică în compoziție. Ardere primară uniformă. Puternice urme de ardere secundară. Buza îngroşată, rotunjită, înălțată vertical, cu şănțuire internă pentru capac. Analogii: Popilian 1976, 180, nr. 333, pl. XXXIV/333, tip 3 (sec. II-III); Brukner 1981, 105, nr. 59, pl. 114/59 (sec. I-III); NicolićDordević 2000, 84, tip II/46 (sec. II); Bolindeț et alii 2003, 327, nr. 52, fig. 23/52 (sec. II); Muşețeanu 2003, pl. 38/46 (sec. II). Datare: sfârşitul sec. II. Pl. XI/52.

53. Oală (fragmentară, se păstrează un fragment din bază cu corp); S 003; $\square$ 5/a; a = 0,25 $\mathrm{m} ; \mathrm{db}=9 \mathrm{~cm} ; \mathrm{hp}=5,3 \mathrm{~cm}$. Pastă semifină, de culoare portocalie (5YR 6/6), cu incluziuni de cuarț alb şi cenuşiu, oxizi de fier, pirită şi rare paiete fine de mică în compoziție. Ardere primară incompletă. Urme de ardere secundară. Baza dreaptă. Analogii: Heukemes 1964, 75, nr. 154, pl. 19/154 (sec. II); Nicolić-Dordević 2000, 79, tip II/33 (începutul sec. III); Damian et alii 2003, 95, nr. 41, fig. 29/41 (sec. II). Pl. XI/53.

54. Oală (fragmentară, se păstrează şase fragmente din corp, cu dimensiuni cuprinse între 1,7-9 cm); S 003; passim; a $=0,40 \mathrm{~m}$. Pastă grosieră, de culoare portocalie (5YR 6/8), cu multe incluziuni de cuarț alb şi cenuşiu, calcit, oxizi de fier, pirită şi rare paiete fine de mică în compoziție. Ardere primară incompletă.

55. Oală (fragmentară, se păstrează patru fragmente din corp, cu dimensiuni cuprinse între 1,5-6,4 cm); S 003; $\square$ 5/d; a = 0,45 m. Pastă grosieră, de culoare portocalie (5YR 6/8), cu multe incluziuni de cuarț alb şi cenuşiu, calcit, oxizi de fier, pirită şi rare paiete fine de mică în compoziție. Ardere primară incompletă.

56. Oală (fragmentară, se păstrează opt fragmente din corp, cu dimensiuni cuprinse între 2,5-5,4 cm); S 003; $\square$ 1-2/a-b; a = 0,73 m. Pastă semifină, de culoare portocalie (5YR 6/6), cu incluziuni de cuarț alb şi cenuşiu, oxizi de fier, pirită şi rare paiete fine de mică în compoziție. Ardere primară uniformă. Uşor afectată de aciditatea solului.

57. Oală (fragmentară, se păstrează trei fragmente din corp, cu dimensiuni cuprinse între 3,5-5,2 cm); S 003; $\square$ 1/a-b; a = 0,45 m. Pastă semifină, de culoare portocalie (5YR 6/6), cu incluziuni de cuarț alb, oxizi de fier, calcit şi mică în compoziție. Ardere primară uniformă. Puternic afectată de aciditatea solului.

58. Opaiț Loeschcke $X$ (fragmentar, se păstrează un fragment din partea inferioară a ciocului); S 003; $\square$ 2/c; a = 0,45 m. Lp = 4,1 cm; $\mathrm{lp}=1,9 \mathrm{~cm}$. Pastă fină, de culoare portocalie (5YR 6/8), cu oxizi de fier şi incluziuni de cuarț alb în compoziție Ardere primară uniformă. Slabe urme de ardere secundară pe interior. Uşor afectat de aciditatea solului. Cioc alungit, cu un arzător. Pl. XII/58.

59. Mojar (fragmentar). S 003; $\square$ 4/c. L = $0,50 \mathrm{~m}$; gr perete $=0,06 \mathrm{~m}$; gr fund $=0,08 \mathrm{~m}$. Roca de bază este vulcano-clastit. Partea inferioară foarte şlefuită. Limita inferioară (fundul) este vizibilă o lărgire a zonei de frecareprobabil zona în care se pisa efectiv cu pistilul. Piesa este fragmentară fiind probabil deteriorată încă din vechime (2 fragmente). Piesa a fost reutilizată la ringul mormântului M 4. Pl. XII/59.

60. Turibulum (fragmentar, se păstrează un fragment din buză); S 004; $\square$ 5/e, a = 0,61 m; $\mathrm{dg}=25 \mathrm{~cm} ; \mathrm{hp}=3,6 \mathrm{~cm}$. Pastă grosieră, de culoare portocalie (5YR 6/8), cu multe incluziuni de cuarț alb şi cenuşiu, calcit, oxizi de fier, pirită şi rare paiete fine de mică în compoziție. Ardere primară uniformă. Urme de ardere secundară. Buza arcuită, uşor înclinată spre exterior este decorată cu alveole mari, realizate prin presarea cu degetele a celor două margini (superioară şi inferioară) când pasta era crudă. Analogii: Popilian 1976, 208, nr. 753, pl. LXII/753, tip 2 (sfârşitul sec. II-începutul sec. III). Datare: sec. II. Pl. XII/60. 
61. Oală (fragmentară, se păstrează un fragment din buză şi altul din bază); S 004; $\square$ 45/b; a = 0,34 m; dg = 11,2 cm; hp = 2,2 cm. Pastă grosieră, de culoare portocalie (5YR 6/8), cu multe incluziuni de cuarț alb şi cenuşiu, calcit, oxizi de fier, pirită şi rare paiete fine de mică în compoziţie. Ardere primară uniformă. Uşor afectată de aciditatea solului. Buza îngroşată, rotunjită, înălțată vertical, cu şănțuire internă pentru capac. Baza dreaptă (?). Analogii: Popilian 1976, 180, nr. 342, pl. XXXIV/342, tip 3 (începutul sec. III); Brukner 1981, 105, nr. 59, pl. 114/59 (sec. I-III); Nicolić-Dordević 2000, 84, tip II/46 (sec. II); Rusu-Bolindeț et alii 2003, 327, nr. 52, fig. 23/52 (sec. II); Muşețeanu 2003, pl. 38/46 (sec. II). Datare: sfârşitul sec. II. Pl. XII/61.

62. Oală (fragmentară, se păstrează un fragment din corp cu dimensiuni de 2,7 $\times 5 \mathrm{~cm}$ ); S 004; $\square$ 5/e; a = 0,25 m. Pastă semifină, de culoare portocalie (5YR 6/6), cu incluziuni de cuarţ alb, oxizi de fier, calcit şi mică în compoziție. Ardere primară uniformă.

63. Oală (fragmentară, se păstrează patru fragmente din corp cu dimensiuni cuprinse între 1,4-4,8 cm); S 004; $\square$ 5/a; a = 0,40 m. Pastă grosieră, de culoare portocalie (5YR 6/6), cu multe incluziuni de cuarț alb, oxizi de fier şi calcit în compoziție. Ardere primară incompletă. Slabe urme de ardere secundară.

64. Oală (fragmentară, se păstrează două fragmente din corp cu dimensiuni cuprinse între 2,4-3,4 cm); S 004; $\square$ 3/a; a = 0,35 m. Pastă grosieră, de culoare portocalie (5YR 6/8), cu multe incluziuni de cuarț alb şi cenuşiu, calcit, oxizi de fier, pirită şi rare paiete fine de mică în compoziţie. Ardere primară incompletă. Uşor afectată de aciditatea solului.

65. Oală (fragmentară, se păstrează patru fragmente din corp cu dimensiuni cuprinse între 1,8-2,2 cm); S 004; $\square$ 5/a; a = 0,35 m. Pastă semifină, de culoare portocalie (5YR 6/6), cu incluziuni de cuarț alb, oxizi de fier, calcit şi mică în compoziție. Ardere primară uniformă. Uşor afectată de aciditatea solului.

66. Opait Loeschcke $\mathbf{X}$ (fragmentar, se păstrează un fragment din bordură); S 004; $\square$ 5/ab; a = 0,43 m. Lp = $3 \mathrm{~cm}$; lp = 1,5 cm. Pastă fină, de culoare portocalie (5YR 6/8), cu incluziuni de oxizi de fier, mică şi rare incluziuni de cuarț alb în compoziţie. Firnis roşu (2.5YR 4/8). Ardere primară uniformă. Bordura îngustă, păstrează un buton. Pl. XII/66.

67. Oală (fragmentară, se păstrează fragmente din buză, corp şi bază); S 005; $\square$ 3-4/e; $\mathrm{a}=0,43 \mathrm{~m} ; \mathrm{dg}=17,2 \mathrm{~cm} ; \mathrm{db}=11 \mathrm{~cm}$. Pastă semifină, de culoare portocalie (5YR 6/6), cu incluziuni de cuarț alb, oxizi de fier, calcit şi mică în compoziție. Ardere primară uniformă. Urme de ardere secundară pe buză. Buza îngroşată, rotunjită înclinată spre exterior, cu şănțuire internă pentru capac. Baza dreaptă. Analogii: Popilian 1976, 182, nr. 369, pl. XXXVI/369, tip 11 (sfârşitul sec. II); Brukner 1981, 105, nr. 55, pl. 113/52 (sec. I-II); Nicolić-Dordević 2000, 70, tip II/10 (sec. II-IV). Datare: sfârşitul sec. IIînceputul sec. III. Pl. XII/67.

68. Oală (fragmentară, se păstrează două fragmente din corp cu dimensiuni cuprinse între 4-5,7 cm); S 005; $\square$ 5/e; a = 0,48 m. Pastă semifină, de culoare portocalie (5YR 6/6), cu incluziuni de cuarț alb, oxizi de fier, calcit şi mică în compoziţie. Ardere primară incompletă. Urme de ardere secundară.

69. Oală (fragmentară, se păstrează un fragment din bază şi trei din corp, cu grad ridicat de fragmentaritate); S 010; $\square$ 5/a; a = 0,37 m. Pastă grosieră, de culoare portocalie (5YR 6/6), cu multe incluziuni de cuarț alb, oxizi de fier şi calcit în compoziție. Ardere primară uniformă. Urme de ardere secundară pe bază.

70. Urcior (fragmentar, se păstrează două fragmente din gât, unul din toartă şi două din corp, cu dimensiuni cuprinse între 3,2-6,2 cm). S 012; $\square$ 3/e; a = 0,38 m. Pastă grosieră, de culoare portocalie (5YR 6/8), cu multe incluziuni de cuarț alb şi cenuşiu, calcit, oxizi de fier, pirită şi rare paiete fine de mică în compoziție. Ardere primară uniformă. Urme de ardere secundară. Imită vasele din bronz. Gât larg, cu urmă de toartă. Toarta canelată.

71. Urcior (fragmentar, se păstrează un fragment din corp cu dimensiuni de 5,6x5,1 cm). S 012; $\square$ 1/c; a = 0,33 m. Pastă grosieră, de culoare portocalie (5YR 6/8), cu multe incluziuni de cuarț alb şi cenuşiu, calcit, oxizi de fier, pirită şi rare paiete fine de mică în compoziție. Ardere primară uniformă. Corp decorat cu o canelură.

72. Dolium (fragmentar, se păstrează un fragment din buză cu corp); S 012; $\square$ 3/c-d; a = 0,65 m; dg = 28 cm; hp = 5,1 cm. Pastă grosieră, 
de culoare portocalie (5YR 6/8), cu multe incluziuni de cuarț alb şi cenuşiu, calcit, oxizi de fier, pirită şi rare paiete fine de mică în compoziție. Ardere primară uniformă. Puternic ars secundar. Buza lată, rotunjită, îngroşată, înclinată spre exterior până la orizontal. Pereți groşi. Analogii: Brukner 1981, 96, nr. 112, pl. 89/112 (sec. II-III); Damian et alii 2003, 118, fig. 26/27 (a doua jumătate a sec. II p.Chr.). Datare: sec. II. Pl. XIII/72.

73. Cupă (fragmentară, se păstrează un fragment din bază cu corp); S 012; $\square$ 2-3/d; a = $0,17 \mathrm{~m} ; \mathrm{db}=2,7 \mathrm{~cm} ; \mathrm{hp}=2,5 \mathrm{~cm}$. Pastă fină, de culoare portocalie (7.5YR 6/6), cu incluziuni de calcit şi oxizi de fier şi cuarț cenuşiu în compoziţie. Ardere primară uniformă. Uşor afectată de aciditatea solului. Bază inelară. Analogii: Popilian 1976, 206, nr. 723, pl. LX/723, tip 4 (sec. II); Nicolić-Dordević 2000, tip IX/3 (sec. II); Rusu-Bolindeț et alii 2003, 398, nr. 75, fig. 28/75 (sec. II). Datare: sec. II. Pl. XIII/73.

74. Opaiț Loeschcke $X$ (fragmentar, se păstrează cinci fragmente din capac); S 012; $\square$ 4/d-e; a = 0,25 m. Lp = $5 \mathrm{~cm}$; lp = 2,5 cm. Pastă fină, de culoare portocalie (7.5YR 6/6), cu incluziuni de calcit şi oxizi de fier şi cuarț cenuşiu în compoziţie. Ardere primară uniformă. Puternic afectat de aciditatea solului. Disc neted, rotund, cu un orificiu de alimentare, delimitat de bordură printr-un cordon, care se îndreaptă spre cioc şi formează un canal. Bordura îngustă, păstrează un buton. Analogii: Iványi 1935, pl. XLIX/7 (sec. II); Kuzmanov 1992, 105, fig. 247 a (sec. II); Alicu 1994, pl. 15/596 (sec. II); Moga et alii 2003, 236, fig. 22/10 (sec. II). Datare: sec. II. Pl. XIII/74.

75. Mojar (fragmentar, se păstrează un fragment din partea superioară). S 015, M 3. L = 0,17 m (max), l = 0,21 m (max), g (buză) =0,07 m, g (perete păstrat) =0,08 m. Roca de bază este vulcano-clastit. Piesa este foarte şlefuită cu urme de frecare verticală. Fața piesei (exteriorul) poartă urme de prelucrare primară (cioplire), fiind vizibile urmele de daltă / zonele de impact cu capul dornului concretizate în mici găurele. „Buza” este prelucrată cu grijă (fasonată). Pl. XIII/75.

76. Mortarium (fragmentar, se păstrează un fragment din buză cu corp); S016; $\square$ 2/d; a = 0,45 m; dg = 25,8 cm; hp = 4,5 cm. Pastă grosieră, de culoare portocalie (5YR 6/8), cu multe incluziuni de cuarţ alb şi cenuşiu, calcit, oxizi de fier, pirită şi rare paiete fine de mică în compoziţie. Ardere primară incompletă. Marginea buzei lată, decorată cu două caneluri, rotunjită, înclinată spre exterior până la orizontală. Pereți groşi. Analogii: Popilian 1976, 172, nr. 214, pl. XVII/214 (sec. II); Brukner 1981, 83, nr. 3, pl. 60/3; Nicolić-Dordević 2000, 17, tip I/1 (sec. IIIIV). Datare: sec. II-III. Pl. XIV/76.

77. Oală (fragmentară, se păstrează un fragment din bază cu corp); S 019; $\square 3 /$; a = 0,30; $\mathrm{db}=6,3 \mathrm{~cm} ; \mathrm{h}=3 \mathrm{~cm}$. Pastă grosieră, de culoare portocalie (5YR 6/8), cu multe incluziuni de cuarț alb şi cenuşiu, calcit, oxizi de fier, pirită şi rare paiete fine de mică în compoziție. Ardere primară uniformă. Baza dreaptă. Analogii: Popilian 1976, 182, nr. 369, pl. XXXVI/369, tip 11 (sfârşitul sec. II); Brukner 1981, 105, nr. 55, pl. 113/52 (sec. III); Nicolić-Dordević 2000, 70, tip II/10 (sec. IIIV). Datare: sfârşitul sec. II-începutul sec. III. Pl. $\mathrm{XIV} / 77$.

78. Oală (fragmentară, se păstrează un fragment din bază şi patru din corp); S020; $\square$ 5-6/be; a = 0,25-0,75 m; db = $8 \mathrm{~cm} ; \mathrm{hp}=2,9 \mathrm{~cm}$. Pastă grosieră, de culoare portocalie (5YR 6/8), cu multe incluziuni de cuarț alb şi cenuşiu, calcit, oxizi de fier, pirită şi rare paiete fine de mică în compoziţie. Ardere primară incompletă. Baza dreaptă. Analogii: Popilian 1976, 182, nr. 369, pl. XXXVI/369, tip 11 (sfârşitul sec. II); Brukner 1981, 105, nr. 55, pl. 113/52 (sec. I-II); Nicolić-Dordević 2000, 70, tip II/10 (sec. II-IV). Datare: sfârşitul sec. II-începutul sec. III. Pl. XIV/78.

79. Urcior (fragmentar, se păstrează fragmente din buză, corp şi bază, reîntregibil ca formă); S 021; $\square$ 5-6/d-e; a = 0,40-0,50 m; dg = $8,2 \mathrm{~cm} ; \mathrm{db}=8,7 \mathrm{~cm}$. Pastă semifină, de culoare portocalie (5YR 6/6), cu incluziuni de cuarț alb, oxizi de fier, calcit şi mică în compoziție. Ardere primară uniformă. Uşor afectat de aciditatea solului. Imită vasele din bronz. Buza înălțată vertical, rotunjită, cu o profilatură externă puternic pronunţată. Gât scurt şi larg. Corp ovoidal. Baza dreaptă. Este prevăzut cu o toartă canelată, ataşată sub buză şi deasupra diametrului maxim. Analogii: Popilian 1976, 188, nr. 459, pl. XLIII/459, tip 2 (a doua jumătate a sec. II); Suceveanu 2000, 153, nr. 17, pl. 72/17 (sec. IIIII); Moga et alii 2003, 241, fig. 27/16 (sec. II). Datare: sec. II. Pl. XIV/79. 
80. Mortarium (fragmentar, se păstrează două fragmente din buză şi patru din corp); S 021; $\square$ 1/e; a = 0,45 m; dg = 26,2 cm; hp = 2,9 cm. Pastă grosieră, de culoare portocalie (5YR 6/8), cu multe incluziuni de cuarț alb şi cenuşiu, calcit, oxizi de fier, pirită şi rare paiete fine de mică în compoziție. Ardere primară incompletă. Uşor afectat de aciditatea solului. Buza lată, rotunjită, înclinată spre exterior până la orizontal. Analogii: Popilian 1976, 172, nr. 214, pl. XVII/214 (sec. II); Brukner 1981, 83, nr. 3, pl. 60/3 (sec. I-II). Datare: sec. II. Pl. $\mathrm{XIV} / 80$.

81. Oală (fragmentară, se păstrează două fragmente din buză, trei din corp şi unul din bază); S 021; $\square$ 3/e; a = 0,76 m; dg = 27 cm; db = 12 cm. Pastă grosieră, de culoare gri-albăstruie (5PB 5/1), cu multe incluziuni de cuarț alb, oxizi de fier şi calcit în compoziţie. Ardere primară uniformă. Buza rotunjită, îngroşată, uşor înclinată spre exterior. Corp parţial păstrat, decorat cu incizii. Baza dreaptă. Analogii: Popilian 1976, 182, nr. 369, pl. XXXVI/369, tip 11 (sfârşitul sec. II); Brukner 1981, 105, nr. 55, pl. 113/52 (sec. III); Nicolić-Dordević 2000, 70, tip II/10 (sec. IIIV). Datare: sfârşitul sec. II-începutul sec. III. Pl. XIV/81.

82. Oală (fragmentară, se păstrează un fragment din buză cu corp); S 021, $\square$ 3/c, a = 0,50 m; dg = 16,2 cm; hp = 5,2 cm. Pastă grosieră, de culoare portocalie (5YR 6/8), cu multe incluziuni de cuarț alb şi cenuşiu, calcit, oxizi de fier, pirită şi rare paiete fine de mică în compoziție. Ardere primară uniformă. Buza îngroşată, rotunjită, uşor înclinată în interior, cu şănțuire internă pentru capac. Analogii: Nicolić-Dordević 2000, 66, tip II/1 (începutul sec. III-sec. V); Damian et alii 2003, 112, fig. 20/1 (începutul sec. III); Muşețeanu 2003, pl. 36/18 (sec. II). Datare: începutul sec. III. Pl. XV/82.

83. Oală (fragmentară, se păstrează un fragment din buză cu corp); S 021; $\square$ 3/e; a = 0,76 m; dg = 15,5 cm; hp = 2,7 cm. Pastă grosieră, de culoare portocalie (5YR 6/8), cu multe incluziuni de cuarț alb şi cenuşiu, calcit, oxizi de fier, pirită şi rare paiete fine de mică în compoziție. Ardere primară uniformă. Urme de ardere secundară. Buza îngroşată, rotunjită, înălţată vertical, cu şănţuire internă pentru capac. Analogii: Popilian 1976, 180, nr. 342, pl. XXXIV/342, tip 3 (începutul sec. III); Brukner 1981, 105, nr. 59, pl. 114/59 (sec. I-III); Nicolić-Dordević 2000, 84, tip II/46 (sec. II); Rusu-
Bolindeț et alii 2003, 327, nr. 52, fig. 23/52 (sec. II); Muşețeanu 2003, pl. 38/46 (sec. II). Datare: sfârşitul sec. II. Pl. XV/83.

84. Cupă (fragmentară, se păstrează un fragment din bază cu corp); S 021; $\square$ 4/d; a = 0,65 m; $d b=3,6 \mathrm{~cm} ; \mathrm{hp}=3,7 \mathrm{~cm}$. Pastă fină, de culoare brun-gălbuie (10YR 6/4), cu incluziuni moderate de oxizi de fier şi mică în compoziție. Ardere primară uniformă. Baza inelară, cu un mic umbo în centru. Analogii: Popilian 1976, 206, nr. 727, pl. LX/727, tip 4 (sec. II); Nicolić-Dordević 2000, 161, tip IX/3 (sec. II). Datare: sec. II. Pl. $\mathrm{XV} / 84$.

85. Cupă (fragmentară, se păstrează un fragment din bază cu corp); S 021; $\square$ 3/e; a = 0,76 $\mathrm{m} ; \mathrm{db}=3,4 \mathrm{~cm} ; \mathrm{hp}=2,3 \mathrm{~cm}$. Pastă fină, de culoare cenuşie (5Y 5/1), cu incluziuni moderate de oxizi de fier, cuarț alb şi cenuşiu, rare incluziuni de calcit în compoziție. Ardere primară uniformă. Uşor afectată de aciditatea solului. Baza inelară, uşor concavă. Analogii: Popilian 1976, 206, nr. 723, pl. LX/723, tip 4 (sec. II); NicolićDordević 2000, 176, tip IX/52 (sec. II); RusuBolindeț et alii 2003, p. 427, fig. 32/92 (sec. II). Datare: sec. II. Pl. XV/85.

86. Opait (fragmentar, se păstrează fragmente din rezervor şi bază); S 021, $\square$ 5/e, a = $0,62 \mathrm{~m} ; \mathrm{Lp}=4,9 \mathrm{~cm} ; \mathrm{lp}=4,4 \mathrm{~cm} ; \mathrm{hp}=1,6 \mathrm{~cm}$. Pastă fină, de culoare portocalie (7.5YR 6/6), cu incluziuni de calcit şi oxizi de fier şi cuarț cenuşiu în compoziție. Ardere primară incompletă. Uşor afectat de aciditatea solului. Rezervor tronconic. Baza uşor concavă este delimitată de două cercuri concentrice incizate. Analogii: Iványi 1935, pl. XLIX/7 (sec. II); Kuzmanov 1992, 105, fig. 247 a (sec. II); Alicu 1994, pl. 15/558 (sec. II); Moga et alii 2003, 236, fig. 22/10 (sec. II). Datare: sec. II. Pl. XV/86.

87. Cupă (fragmentară, întregibilă ca formă); S 022; $\square$ 3/a; a = 0,22 m; dg = 5,9 cm; dmax = 8,4 cm; db = $3 \mathrm{~cm} ; \mathrm{h}=7,4 \mathrm{~cm}$. Pastă fină, de culoare portocalie (7.5 YR 6/6), cu o cantitate moderată de incluziuni de calcit şi oxizi de fier şi rare incluziuni de cuarț cenuşiu în compoziție. Ardere primară uniformă. Urme de ardere secundară pe buză şi corp. Uşor afectată de aciditatea solului. Buza rotunjită, înălțată vertical. Corp globular. Baza inelară. Este prevăzută cu o toartă necanelată, ataşată pe buză şi pe diametrul maxim. Analogii: Zotović-Jordović 1990, pl. XLV/5 (sec. II); Nicolić-Dordević 2000, 
176, tip IX/52 (sec. II); Suceveanu 2000, 102, nr. 15, pl. 42/15 (ultimul sfert al sec. II-începutul sec. III). Datare: sec. II. Pl. XV/87.

88. Urcior (fragmentar, se păstrează un fragment din bază şi două din corp); S 030; $\square$ 1/e-f; $\mathrm{a}=0,41 \mathrm{~m} ; \mathrm{db}=10,3 \mathrm{~cm} ; \mathrm{hp}=1,6 \mathrm{~cm}$. Pastă fină, de culoare portocalie (7.5 YR 6/6), cu o cantitate moderată de incluziuni de calcit şi oxizi de fier şi rare incluziuni de cuarț cenuşiu în compoziţie. Firnis roşu (10R 4/6). Ardere primară uniformă. Uşor afectat de aciditatea solului. Baza inelară. Analogii: Popilian 1976, 190, nr. 481, pl. XLV/481, tip 5 (sec. II); Nicolić-Dordević 2000, 138, tip VII/8 (sec. II); Moga et alii 2003, 232, fig. 18/10 (sec. II). Datare: sec. II. Pl. XV/88.

89. Oală (fragmentară, se păstrează un fragment din bază cu corp); S 030; $\square$ 1/e-f; a = $0,41 \mathrm{~m} ; \mathrm{db}=9 \mathrm{~cm} ; \mathrm{hp}=3 \mathrm{~cm}$. Pastă semifină, de culoare portocalie (5YR 6/6), cu incluziuni de cuarț alb, oxizi de fier, calcit şi mică în compoziție. Ardere primară incompletă. Baza dreaptă. Analogii: Popilian 1976, 182, nr. 369, pl. XXXVI/369, tip 11 (sfârşitul sec. II); Brukner 1981, 105, nr. 55, pl. 113/52 (sec. I-II); NicolićDordević 2000, 70, tipII/10 (sec. II-IV). Datare: sfârşitul sec. II-începutul sec. III.

90. Oală (fragmentară, se păstrează un fragment din buză cu dimensiuni de 3,5x1,2 cm); S 030; $\square$ 1/e-f; a = 0,41 m. Pastă grosieră, de culoare portocalie (5YR 6/8), cu multe incluziuni de cuarț alb şi cenuşiu, calcit, oxizi de fier, pirită şi rare paiete fine de mică în compoziție. Ardere primară uniformă. Buza îngroşată, rotunjită.

\section{ABREVIERI}

ActaMN - Acta Musei Napocensis, Cluj-Napoca.

AIIACluj - Anuarul Institutului de Istorie şi Arheologie, Cluj-Napoca.

Alburnus Maior I — Alburnus Maior, vol. I (coord. P. Damian), Bucureşti, 2003.

Aquitania - Aquitania. Une revue inter-régionale d'archéologie,

CCA 2001 (2002) - Cronica Cercetărilor Arheologice din România, campania 2001; a XXXVI-a Sesiune Naţională de Rapoarte Arheologice, 28 mai-1 iunie 2002, Buziaş (Bucureşti, 2002).

CCA 2002 (2003) - Cronica Cercetărilor Arheologice din România, campania 2002; a XXXVII-a Sesiune Naţională de Rapoarte Arheologice, 2-6 iunie 2003, Covasna (Bucureşti, 2003).

CCA 2003 (2004) - Cronica Cercetărilor Arheologice din România, campania 2003; a XXXVIII-a Sesiune Naţională de Rapoarte Arheologice, 26-29 mai 2004, Cluj-Napoca (Bucureşti, 2004).

Dacia - Dacia. Nouvelle Série. Revue d'Archéologie et d'Histoire Ancienne, Bucarest.

Pontica - Pontica. Studii şi materiale de istorie, arheologie şi muzeografie, Constanța.

RE - A.Pauly, G.Wissowa, Real Encyclopedie der Klassichen Altertumswissenschaft, Stuttgart, 1893 sqq.

Der Anschnitt — Der Anschnitt: Zeitschrift für Kunst und Kultur im Bergbau, Bochum.

Funeraria Dacoromana - Funeraria Dacoromana. Arheologia funerară a Daciei Romane (coord. M. Bărbulescu), Cluj-Napoca, 2003.

Paleohistoria - Palaeohistoria. Acta et communicationes Instituti bio-archaeologici Universitatis Groninganae

Pallas - Pallas, Press Universitaires du Mirail, Toulouse.

Ziva Antiqua - Živa antika. Antiquité vivante

Bonner Jahrbücher — Bonner Jahrbücher des Rheinischen Landesmuseums in Bonn

\section{BIBLIOGRAFIE}

Alicu 1994 - D. Alicu, Opaițele romane, Ulpia Traiana Sarmizegetusa, Bucureşti.

Ardaillon 1897 — E. Ardaillon, Les mines du Laurion dans l'antiquité, Paris.

Băluță 1981 - C. L. Băluță, Mortaria ştampilate commune în Dacia şi Moesia Inferior, Pontica, 14, p. 263-267. 
Blázquez, Domergue 2002 - J. M. Blázquez Martínez, C. Domergue, La Loba (Fuenteobejuna, province de Cordoue, Espagne). La mine et la village minier antiques, Bordeaux.

Boroneanț 2000 - V. Boroneanț, Arheologia peşterilor şi minelor din România, Bucureşti.

Bolindeț et alii 2003 - Viorica Rusu-Bolindeț, Cristian Roman, Emilian Bota, Adriana Isac, Adela Paki, Felix Marcu, Monica Bodea, Forme de habitat în punctul Balea, Alburnus Maior I, p. 387-432.

Brukner 1981 - Olga Brukner, Rimska Keramika u Jugoslavenskom delu provincije Donje Panonije, Beograd. Butler, Van der Waals 1966 - J. J. Butler, J. D. Van der Waals, Bell Beakers and Early Metalworking, în Paleohistoria, 12, p. 63-73.

Carcopino 1924 - J. Carcopino, Les richesses des Daces et le redressment de L'Empire sous Trajan, în Dacia, 1, p. 28-34.

Carcopino 1934 - J. Carcopino, Un retour à l'impérialisme de conquête: l'or des Daces, Points de vue sur l’ impérialisme romain, Paris.

Cauuet 1988 - B. Cauuet, La mine antique des Fouilloux (Jumilhac, Dordogne) : les premiers résultats de la fouille, în Aquitania, Bordeaux, t. 6, p. 181-190.

Cauuet 1993 - B. Cauuet, Mine d'or de Cros Gallet-nord (Le Chalard, Haute - Vienne), în Bilan Scientifique du Service Régional de l'Archéologie du Limousin, Limoges, 1993, p. 41-42.

Cauuet 1994 - B. Cauuet, Mine d'or de Cros Gallet-nord (Le Chalard, Haute - Vienne), Bilan Scientifique du Service Régional de l'Archéologie du Limousin, Limoges, p. 42-44.

Cauuet 1995 - B. Cauuet, L'Or des Gaulois, Paris, 1995.

Cauuet et aliii 2003 - B. Cauuet, B. Ancel, Chr. Rico, C. Tămaş, Rețelele miniere antice. Misiunile arheologice franceze 1999-2001, în Alburnus Maior I (ed. Paul Damian), Bucureşti.

Cauuet 2004 - Beatrice Cauuet, L'or des Celtes du Limousin, Limoges.

Cauuret, Tollon 1999 - B. Cauuret, F. Tollon, Problèmes posés par le traitement des minerais et la récupération de l'or dans les mines gauloises du Limousin, L'Or dans l'Antiquité de la Mine à l'Objet, (éd. B. Cauuet), Actes du Colloque International de Limoges 1994, Supplément 9 Aquitania, Bordeaux, p. 185-198.

Christescu 2004 - V. Christescu, Viaţa economică a Daciei Romane, Bucureşti, (C. C. Petolescu ed.).

Cizek 1980 - E. Cizek, Epoca lui Traiana, Bucureşti.

Cserni 1901 - B. Cserni, Alsófehér vármegye monográfiája, 2/1, Aiud.

Daicoviciu 1945 - C. Daicoviciu, La Transylvanie dans l'antiquité, Bucuresti.

Daicoviciu 1972 - H. Daicoviciu, Dacia de la Burebista la cucerirea romană, Bucureşti.

Daicoviciu Piso 1975 - H. Daicoviciu, I. Piso, Sarmizegetusa şi războaiele marcomanice, ActaMN, 12, p. 159-163.

Damian et alii 2003 - P. Damian, M. Simion, A. Bâltâc, S. Oța, G. Bălan, M. Vasile, D. Vleja, Forme de habitat în punctele Hop - Botar şi Tăul Țapului, Alburnus Maior I, p. 81-122.

Davies 1935 - O. Davies, Roman mines in Europe, Oxford, 1935.

Domergue 1990 - Cl. Domergue, Les mines de la Péninsule Ibérique dans l'antiquité romaine, Roma.

Domergue, Sillères 2002 - Cl. Domergue, P. Sillères, La Loba: le village de mineurs et de metallurgists d'époque romaine, în La Loba (Fuenteobejuna, Cordoue, Espagne); La Mine et le village Minier Antiques (ed. J. M. Blázquez, Cl. Domergue, P. Sillières), Bordeaux, 2002, p. 85-162.

Dušanic 1971 - S. Dušanic, Metalla Municipii Dardanorum, în Ziva Antiqua, 21, p. 241-261.

Dušanic 1977 - S. Dušanic, Aspects of Roman Mining in Noricum, Pannonia, Dalmatia and Moesia Superior, ANRW, II, 6, p. 52-94.

Forbes 1950 - R. J. Forbes, Metallurgy in antiquity: A notebook for archaeologists and technologists, Leiden. Gonzalo y Tarin 1888 - J. Gonzalo y Tarin, Descripción física , geológica, y minera de la provincia Huelva, 2, Madrid.

Halleux 1985 - R. Halleux, Méthodes d'essai et d’affinage des aliiages aurifès dans L'Antiquité et au Moyen Ages, în L’or monnayé, vol. 1 Purification et altérations de Rome a Byzance (ed. C. Morrisson et al.), Cahiers Ernest Babelon, 2, p. 39-77.

Haley 1978 - J. F. Haley, Mining and Metallurgy in the Greek and Roman World, Londra.

Heukemes 1964 - B. Heukemes, Römische keramik aus Heidelberg, Bonn.

Hilgers 1969 - W. Hilgers, Lateinische Gefässnamen, Bonn. 
Hüssen 2000 - C. M. Hüssen, Die römische Besiedlung im Umland von Heilbronn, Stuttgart.

Iványi 1935 - Dóra Iványi, Die Panninischen Lampen, Eine typologisch - chronologissche übersicht, Budapest. Kuzmanov 1992 - G. Kuzmanov, Anticiki Lampu, Kolekțiia na naționaliia arheologiceski muzei, Sofia. Laporte 1965a - A. Laporte, L'archéologie et l'histoire au service de la recherche minière. Un exemple d'application: les gisements aurifères du Limousin et de la Marche (I), în Bulletin du Bureau de Recherches Géologiques et Minières, 1, p. 45-78.

Laporte 1965a - A. Laporte, L'archéologie et l'histoire au service de la recherche minière. Un exemple d'application: les gisements aurifères du Limousin et de la Marche (II), în Bulletin du Bureau de Recherches Géologiques et Minières, 2, p. 23-111.

Macrea 1969 - M. Macrea, Viața în Dacia Romană, Bucureşti.

Maghiar, Olteanu 1970 - N. Maghiar, Şt. Olteanu, Din Istoria Mineritului Românesc, Bucureşti.

Matschke 2002 - K. P. Matschke, Mining, în The Economic History of Byzantium: From the Seventh through the Fifteenth Century (ed. A. E. Laiou), Dumbarton Oaks, 2002, p. 115-120.

Meyer 1997 - C. Meyer, Bir Umm Fawakhir: Insights into Ancient Egyptian Mining, în Journal of The Minerals, Metals \& Materials Society, 49, 3, p. 64-68.

Moga et alii 2003 - V. Moga, C. Inel, A. Gligor, A. Dragotă, Necropola de incinerație din punctual Hop, Alburnus Maior I, p. 193-251.

Mușețeanu 2003 - C. Muşețeanu, Atelierele ceramice romane de la Durostorum, Bucureşti.

Nicolić-Dordević 2000 - Snežana Nicolić-Dordević, Antička Keramika Singidunuma, Singidunum 2, Beograd, p. 11-244.

Noeske 1977 - H. Chr. Noeske, Studien zur Verwaltung und Bevölkerung der dakischen Goldbergwerke in römischer Zeit,în Bonner Jahrbücher, 177, p. 271-416.

Palfy 1916 - M. Palfy, Geologische Verhältnisse und Erzgänge der Bergbaue des siebenbürgeschen Erzgebirges, Budapest, p. 76.

Patsch 1937 - C. Patsch, Der Kampf um den Donauraum unter Domitian und Trajan, in Beiträge zur Völkerkunde von Südosteuropa, V, 2, Wien-Leipzig.

Pâslaru, Bărbulescu 2003 - M. Pâslaru, M. Bărbulescu, Ritualuri la înmormântare, în Funeraria Dacoromana, p. 19-43.

Photiades, Morin 2005 - A. Photiades, D. Morin, Nouvelles recherches sur les mines antiques du Laurion (Grèce), în Pallas, 67, p. 327-358.

Pigagnol 1967 - A. Pigagnol, La conquête romaine, Paris.

Pittioni 1958 - R. Pittioni, Der Schmelzplatz Nr. 13 des Bergbaugebietes Jochberg bei Kitzbühel, Tirol, în Archaeologia Austriaca, 3, p. 19-40.

Popescu 1967 - E. Popescu, Aspecte ale colonizării şi romanizării în Dacia şi Scythia în lumina unor inscripții din muzee bucureştene, Studii Clasice, 9, 1967, p. 182-190.

Popilian 1976 - Gh. Popilian, Ceramica romană din Oltenia, Craiova.

Ramin 1977 - J. Ramin, La technique minière et métallurgique des Anciens, Bruxelles.

Rostovtzeff 1926 - M. Rostovtzeff, The Social and Economic History of the Roman Empire, Oxford.

Rothemberg 1972 - B. Rothemberg, Timna, Valley of the Biblical Coper Mines, London.

Sagui 1940 - C. Sagui, Les mines anciennes du Limousin (region de Saint-Yrieix), în Bulletin de la Société Archéologique et Historique du Limousin, 78, 1940, p. 250-277.

Sánchez-Palencia Ramos - F. J. Sánchez-Palencia, Römischer Goldbergbau im Nordwesten Spaniens. Ein Forschungsbericht, în Der Ausschnitt, 2/3.

Simion et alii 2004 - Mihaela Simion, V. Apostol, D, Vleja, Monumentul funerar circular, Bucureşti.

Stanciu 1942 - V. Stanciu, Aurul Daciei şi Imperiul Roman, Timişoara.

Strobel 1984 - K. Strobel, Untersuchungen zu den Dakerkriegen Trajans. Studien zur Geschichte des mittleren und unteren Donauraumes in der Hohen Kaiserzeit, Bonn, (Antiquitas 1, 33).

Strobel 1998 - K. Strobel, Dacii. Despre complexitatea mărimilor etnice, politice şi culturale ale spațiului Dunării de Jos, în SCIVA 49, 1, p. 61-95.

Suceveanu 2000 - Al. Suceveanu, Histria X. La céramique romaine de $I^{\text {er }}$-III $e^{e}$ siècles ap. J. C., Bucureşti. Tovar, Blázquez 1975 - A. Tovar, J. M. Blázquez, Historia de la Hispania romana, Madrid, 1975. 
Tudor 1957 — D. Tudor, Răscoale şi atacuri barbare în Dacia romană, Bucureşti.

Tudor 1968 - D.Tudor, Oraşe, Târguri şi Sate în Dacia Romană, Bucureşti, 1968.

von Born 1870 - Ignaz von Born, Voyage mineralogique fait en Hongrie et en Transilvanie, Paris.

Zotović-Jordović 1990 - Lj. Zotović, Č Jordović, Nekropola Više Grobalja, Viminacium I, Beograd.

Wilkes 1969 - J. Wilkes, Dalmatia, Londra.

Wollmann 1973 - V. Wollmannn, Hărți privind exploatările miniere de la Dognecea în a doua jumătate a secolului al XVIII - lea, în Banatica, 2, p. 187-198.

Wollmann 1986 - V. Wollmann, Un lucus la Alburnus Maior, în AIIACluj, 17, 1985-1986, p. 253-295.

Wollmann 1996 - V. Wollmann, Mineritul metalifer, extragerea sării şi carierele de piatră în Dacia Romană, Cluj.

\section{ILLUSTRATION LIST}

Pl. I. Roşia Montană. Investigated area. General plan.

PI. II. Roşia Montană, Jig-Piciorag. General plan, stratigraphical units.

Pl. III. Roşia Montană, Jig-Piciorag. General plan, necropolis, workshop.

Pl. IV. Roşia Montană, Jig-Piciorag. Workshop, general general.

PI. V. Roşia Montană, Jig-Piciorag. Hearth V1, horizontal plan.

PI. VI. Roşia Montană, Jig-Piciorag. Images of the workshop area.

PI. VII. Roşia Montană, Jig-Piciorag. Objects found in the workshop, rooms 1-2; cat. no. 1-3, 7-8.

PI. VIII. Roşia Montană, Jig-Piciorag. Objects found in the workshop, rooms 4-5; cat . no. 11-15.

PI. IX. Roşia Montană, Jig-Piciorag. Objects found in the workshop, room 5 and channel c1; cat. no. 16-19.

PI. X. Roşia Montană, Jig-Piciorag. Objects found in the workshop, the V1 hearth and outside the constructive structure; cat. no. 23-28, 34-43.

PI. XI. Roşia Montană, Jig-Piciorag. Discoveries outside the constructive structure; cat. no. 44-46, 49-53.

PI. XII. Roşia Montană, Jig-Piciorag. Discoveries outside the constructive structure; cat. no. 58-61, 66-67.

Pl. XIII. Roşia Montană, Jig-Piciorag. Discoveries outside the constructive structure; cat. no. 72-75.

PI. XIV. Roşia Montană, Jig-Piciorag. Discoveries outside the constructive structure; cat. no. 76-81.

PI. XV. Roşia Montană, Jig-Piciorag. Discoveries outside the constructive structures; cat. no. 82-88.

\section{AUTORI}

\section{Mihaela Simion}

Muzeul Naţional de Istorie a României

arheoprev@mnir.ro

\section{Ionuț Bocan}

Muzeul Național de Istorie a României

ionutzbocan@gmail.com

\section{Decebal Vleja}

Muzeul Național de Istorie a României

decebal_vleja@yahoo.com

\section{Emil Dumitraşcu}

Muzeul Național de Istorie a României

emildumitrascuionut@yahoo.com 